\title{
Social interactions and the retirement age
}

Niels Vermeer

Maarten van Rooij

Daniel van Vuuren 



\title{
Social interactions and the retirement age
}

\author{
Niels Vermeer (CPB, Netspar and Tilburg University) \\ Maarten van Rooij (De Nederlandsche Bank and Netspar) \\ Daniel van Vuuren (CPB and Netspar)
}

\begin{abstract}
In this study, we gauge the impact of social interactions on individual retirement preferences. A survey including self-assessments and vignette questions shows that individual preferences are affected by preferences and actual retirement behavior of the social environment. Retirement from paid work depends on the retirement age of relatives, friends, colleagues and acquaintances. Information and advice provided by the social environment play a role in the retirement decision. A majority of respondents would postpone retirement when their social environment retires later. A one year increase in the social environment's retirement age leads to an average increase of three months in the individual retirement age. In addition, people tend to stick more to the state pension age than to other retirement ages, which suggests a norm about retirement at the state pension age.
\end{abstract}

\section{Introduction 1}

Worldwide, governments are reforming pension schemes to tackle concerns about fiscal sustainability due to aging populations. The concerns are exacerbated by the recent economic downturn. Many countries are increasing the statutory retirement age (see OECD, 2011 for an overview). Typically, this is the age at which individuals are entitled to full retirement benefits. ${ }^{2}$ The purpose of higher statutory retirement ages is to reduce government expenditures and to raise labor force participation as well.

Increases in the statutory retirement age have substantial impact on the labor participation rates of older workers. Aggregate retirement patterns show 'retirement peaks' at key institutional ages in the US (Gruber and Wise, 1999) and the Netherlands (Van Erp et al., 2013). Indeed, the evidence shows that an increase of the statutory retirement age leads to an increase of the mean retirement age. Mastrobuoni (2009) documents a raise of 6 months in the mean retirement age after a reform that increased the statutory retirement age with one year.

Why is the statutory retirement age important for retirement behavior? An obvious explanation is that it serves as a 'focal point'. Individuals consider their planned retirement age in relation to the statutory retirement age. Deviations may lead to disutility due to both financial and non-financial reasons. The design of retirement schemes is not always actuarially neutral and retirement at different ages than the standard age may entail an implicit financial penalty. Workers can perceive the statutory retirement age as an implicit advice to retire at that specific age. Or they take this age as a point of reference when starting to think about and plan for retirement. They perhaps perceive an early retirement plan with lower benefits as a loss compared to a plan with higher benefits starting at the statutory retirement age. We explore yet another explanation and study whether social interactions feed into individual retirement behavior?

\footnotetext{
${ }^{1}$ The authors thank Yvonne Adema, Viola Angelini, Jochem de Bresser, Tabea Bucher-Koenen, Rik Dillingh, Frank van Erp, Johannes Hers, Arthur van Soest, Adriaan Soetevent, Bas ter Weel, Joachim Winter and participants of the Netspar Pension day, de Nederlandse Economen Dag and seminars at CPB (Netherlands Bureau for Economic Policy Analysis), DNB (Dutch Central Bank), and MEA/University of Munich for valuable comments. Additionally, the authors thank Mauro Mastrogiacomo and Arthur van Soest for fruitful discussions in designing the survey and CentERdata for excellent support in implementing the survey. The authors are grateful to Netspar for research funding. Views expressed are those of the authors and do not necessarily reflect official positions of De Nederlandsche Bank and CPB.

${ }^{2}$ In some countries it is possible to choose the date when to start collecting benefits. On other countries, the retirement age may depend on the number of years contributed.
} 
The goal of this paper is to gain insight into the relation between retirement behavior of the social environment and individual retirement plans. For this purpose, we collect data in a controlled experiment setting. In particular, we have designed a survey with self-assessments and a series of vignette questions. The selfassessments examine from whom respondents expect to receive explicit or implicit advice about the decision when to retire and whose personal situation they take into account. The vignette questions portray a fictive person making a retirement plan and describe a change in retirement behavior by the social environment. The vignettes are designed as to keep financial incentives constant and varying the retirement age of the social environment only. The exogenous change in the retirement age of the social environment enables identification of a causal effect on the individual retirement age.

To deepen our knowledge on the mechanisms behind the influence of the social environment, we vary the format of the vignette questions between respondents. The reason for the social environment to retire at a later age is framed in four different ways. Each respondent is confronted with either a male or a female fictive person and a different composition of the social environment. This enables an investigation of what factors are relevant for social interactions and the retirement planning of the respondents.

To preview our main conclusions: we show that social interactions play an important role in retirement decisions. First, individuals receive advice from a broad social environment, including family, friends and coworkers, and often, take the advice into account in their retirement plans. Moreover, they take the personal situation of their social environment into account, in particular of those who stand more close to them. Second, workers are influenced by the retirement age of the social environment. An increased retirement age of the social environment of one year leads to approximately three months later retirement of the individual. We identify a special role for the age of 65 years, which has been the statutory pension age in the Netherlands for over fifty years. This may be related to the formation of social norms connected to specific retirement ages such as the statutory retirement age. As a consequence an increase in the statutory retirement age, while raising the labor participation in the short run, may have a larger effect in the long run.

These findings have important implications for public policy. An increase in the statutory retirement age will first persuade a certain group of individuals to retire later (e.g. as a result of financial incentives or framing). Social interactions create a spill-over effect and change the retirement decision of other individuals as well. In the longer run, social norms may shift along with the increase in the statutory retirement age, increasing the effectiveness of this policy instrument. All in all, the long run labor participation effect of an increase in the statutory retirement age goes beyond the direct short run impact of the change in financial incentives.

The paper is organized as follows. Section 2 considers the theoretical framework and reviews previous studies. Section 3 briefly discusses the Dutch retirement institutions. Section 4 describes our data and research design. Section 5 presents the empirical results. Section 6 concludes with a discussion of the implications.

\section{$2 \quad$ Literature overview}

\subsection{Theoretical framework}

Social interactions influence individual decision making; individual decisions and peer group behaviors are correlated. ${ }^{3}$ Natural experiments for example show an influence of shocks in individual income or consumption on the consumption of other individuals (Angelucci and Giorgi, 2009 and Kuhn et al., 2011). Manski (1993) and Duflo and Saez (2002) distinguish three distinct social effects: exogenous, endogenous and correlated social effects. Exogenous social effects entail the influence of observable characteristics of the peer group on individual behavior, conditional on observable characteristics of the individual. Older coworkers (the peer group in this case) could influence the individual retirement age. As they are older and could be at the verge of

\footnotetext{
${ }^{3}$ For instance, Hanushek et al. (2003) highlight the role of peer effects on student achievement. Topa (2001) finds that individuals are more likely to be employed if the members of their social networks are employed and attributes this to sharing job information throughout social networks.
} 
retirement, this might induce somewhat younger individuals to think about retirement and plan accordingly. In other words, individual behavior is guided by background characteristics of peers and not by actions or behavior of the peer group. Endogenous social effects mean that peer group behavior influences individual behavior. This implies a direct link between peer group and individual actions that is not related to observable characteristics. For instance, the retirement of coworkers (the peer group) sets an example and influences the individual retirement age. As an example, he or she could imitate the typical retirement age of the coworkers. Finally, common factors among individual and peer group can determine both behavior of the peer group and the individual. These are called correlated social effects. For instance, the presence of common retirement plans can influence the retirement age of both the individual as the peer group (in this case the co-workers). Changing the peer group of an individual does not lead to changes in other individual outcomes in this case.

In the case of endogenous social interactions policy interventions can have multiplier effects. For instance, an informational intervention applied to some participants can lead to a higher retirement age for those participants. The changed behavior of these participants may cause the retirement age of non-informed individuals to increase as well. This means that policy interventions have a 'spill-over' effect on non-targeted individuals. In general, policies may indirectly influence the behavior of untreated individuals via a direct effect on treated individuals and the overall effect of a policy intervention is then larger than the effect on the targeted individuals alone.

But this does not automatically imply that a multiplier effect is always present in the case of endogenous social effects. Bernheim (1994) discusses a model in which individuals want to conform to a social norm.

Conformance to a social norm has impact on the status that individuals care about, and they will only depart from the social norm when their own preference is vastly different. If the social norm itself is static then there is no link between the number of individuals following the norm and the norm itself. Actions of individuals inform other individuals about the prevailing norm but do not alter the norm. Policy interventions will not influence behavior of untreated individuals, provided the policy intervention does not change the norm as individuals already make optimal choices given incentives and the social norm (see Duflo and Saez, 2002). In such a case, multiplier effects will be absent.

If the social norm is not static and its 'strength' increases in the number of individuals adhering to the particular social norm, a multiplier exists. In this sense social norms become endogenous: the social norm depends on the number of individuals following the norm. As public policy could influence the behavior of a number of individuals directly, it can influence the norm in this way. A policy intervention then impacts other individuals via the changed social norm. The literature provides several examples. For instance, Fischer and Huddart (2008) discuss the relevance of social norms with regard to the design of contracts and Lindbeck, Nyberg and Weibull $(1999,2003)$ consider the relation between social norms and collecting welfare benefits. But to what extent are social norms 'sticky'? This matters for the feasibility of interventions. Does the alteration of social norms take generations or does it change almost immediately? There is no agreement in the literature on this issue. Lindbeck et al. (2003) investigate both instantaneous and lagged stigma in the collection of welfare benefits. Lagged stigma introduces dynamics in the alteration of the social norm and leads to more generous benefits and longer lasting effects than instantaneous stigma. Ljunge (2010) studies the take-up of sick leave benefits by different generations in Sweden. He assumes that for a given cohort the reference group is formed by individuals born 2-4 years earlier living in the same county. Lindbeck and Nyberg (2006) and Corneo (2013) study social norms in the context of the welfare state and focus on the link between parents and children. The link between generations represents a much longer time span than in the case of Ljunge.

\subsection{Empirical findings}

Much research focuses at the retirement age, mainly the relation between financial incentives and retirement decisions using structural or reduced-form models (see for instance, Coile and Gruber, 2007, and Gustman and 
Steinmeier, 2013). These studies rely on the variation in retirement wealth (e.g. claims on Social Security) among individuals and may include forward-looking measures. ${ }^{4}$

A central difficulty in estimating retirement age choices is the role of retirement at key institutional ages.

Retirement schemes across countries typically feature institutional ages, like the 'normal retirement age' (i.e. the age at which 'full' retirement benefits are available) and the 'early retirement age' (i.e. the age at which retirement benefits are first available). For instance, in the United States the early (normal) retirement age amounted 62 (65) years of age until 2003. Consequently, the observed retirement pattern shows many individuals retiring at these ages, leading to 'retirement peaks'. These ages are often linked to other institutional features, like the availability of Medicare at the age of 65 that need to be taken into account in explaining retirement decisions. Inclusion of these factors still leaves unexplained 'retirement peaks'. Lumsdaine et al. (1996) systematically investigated a variety of explanations but found no particular reasons for 'excess retirement' at the peaks of 62 and 65 years of age. They conclude that the particular popular retirement ages must function as 'the influence of custom or accepted practice'.

Various countries have begun to increase their statutory retirement age. The Social Security reform in the United States of 1983 increased the normal retirement age (NRA) of Social Security from 65 to 66 years in six steps of two months for cohorts born between 1938 and 1943. In 2003 the first cohort reached the raised normal retirement age. In Switzerland the normal retirement age for females was raised in two steps. In 2001 it was raised from 62 to 63 years, followed by a further increase to 64 years in $2005 .^{5}$ The US and Swiss examples imply that different birth cohorts are faced with different normal retirement ages and endogenous selection into treatment is not possible.

The raise in statutory retirement ages for different birth cohorts in these reforms is exploited for treatment evaluations. Mastrobuoni (2009) finds that individuals are sensitive to increases in the normal retirement age (NRA) of Social Security in the US. For every two months increase in the NRA individuals retire on average one month later. Hanel and Riphahn (2012) study the effect of the reform for Swiss female workers. An increase of the NRA with one year (from 62 to 63 years of age) generates an increase of 2.3 months in expected retirement age; an increase with two years (from 62 to 64 years of age) generates an increase of 7.7 months. ${ }^{6}$

\section{Dutch retirement institutions}

The Dutch retirement system consists of different 'pillars'. The first pillar consists of flat state pension benefit, unrelated to the earnings history. Eligibility is determined by age and the number of years one lived in the Netherlands. ${ }^{7}$ Contributions paid over the life-cycle are not taken into account for eligibility nor for the level of the benefits. The payment of benefits starts at the statutory retirement age. It is not possible to claim earlier (later) and to receive lower (higher) benefits for the rest of the lifetime.

Since the introduction of old age state pensions in 1957 in the Netherlands, the first pillar statutory retirement age was fixed at 65 years. In 2010 it was announced that the statutory retirement age would eventually be coupled to the life-expectancy. A transitional agreement phases this coupling in gradually, starting in 2013. This means that different birth cohorts are confronted with different statutory pension ages. In 2021 the statutory retirement age will be 67 years (Table 1). Cohorts reaching the age of 67 after 2021 will face higher statutory retirement ages, depending on further increases in life-expectancy.

\footnotetext{
${ }^{4}$ For instance, it can be taken into account that Social Security benefits in the US increase roughly 7 percentage points for each year retirement is postponed

${ }^{5}$ The reform introduced the possibility for early retirement. Hence, it was still possible to retire at age 62 . The benefits were cut $3.4 \%$ if collected one year earlier. In case benefits were collected two years earlier the permanent cut amounts $6.8 \%$.

${ }^{6}$ The magnitude of the results of Mastrobuoni and Hanel and Riphahn are larger than predicted in simulation studies (see for instance Coile and Gruber, 2000). These studies included only the impact of changed financial incentives by the reform, while Mastrobuoni and Hanel and Riphahn measure the total effect of an increase in the NRA including non-financial determinants of retirement behavior.

${ }^{7}$ Every year lived in the Netherlands when being between 15 and 65 years of age entitles one to $2 \%$ of the total state pension benefits.
} 
Table 1 Details on increasing the statutory retirement age

\begin{tabular}{|l|c|c|c|c|c|c|c|c|c|}
\hline Year & $\mathbf{2 0 1 3}$ & $\mathbf{2 0 1 4}$ & $\mathbf{2 0 1 5}$ & $\mathbf{2 0 1 6}$ & $\mathbf{2 0 1 7}$ & $\mathbf{2 0 1 8}$ & $\mathbf{2 0 1 9}$ & $\mathbf{2 0 2 0}$ & $\mathbf{2 0 2 1}$ \\
\hline $\begin{array}{l}\text { Statutory } \\
\text { retirement } \\
\text { age }\end{array}$ & $\begin{array}{l}65+1 \\
\text { month }\end{array}$ & $\begin{array}{c}65+2 \\
\text { months }\end{array}$ & $\begin{array}{c}65+3 \\
\text { months }\end{array}$ & $\begin{array}{c}65+6 \\
\text { months }\end{array}$ & $\begin{array}{c}65+9 \\
\text { months }\end{array}$ & 66 & $\begin{array}{c}66+4 \\
\text { months }\end{array}$ & $\begin{array}{c}66+8 \\
\text { months }\end{array}$ & 67 \\
\hline
\end{tabular}

Source: Ministry of Social Affairs and Employment (http://www.rijksoverheid.nl/onderwerpen/algemene-ouderdomswet-aow/wijzigingenin-de-aow, in Dutch)

The second pillar of the pension scheme consists of mandatory retirement savings. These schemes are often organized at the company or the sectoral level. Employment in a specific company or branch determines enrollment in the accompanying pension fund or insurer. Individuals have no say in the level of pension contributions or the investment policy in these retirement plans (Van Rooij et al., 2007). This pillar enables early or late retirement depending on individual preferences and the retirement plan. The age of the benefit takeup has consequences on the expected number of years of collecting benefits and thus for the level of benefits. The pension plans in pillar can be either defined-contribution (DC) or defined-benefit (DB). So the level of benefits depends also on paid contributions or income during the life-cycle. Contributions are tax-deductible and taxes are levied during the pay-out phase. In general, the tax deferral leads to a clear tax advantage. Benefits are paid in the form of a lifelong annuity.

The third pillar concerns voluntary individual retirement savings with special fiscal treatment. This pillar is relatively small. It is directed at individuals who do not have access to the second pillar (e.g. the self-employed) of have accumulated little savings with their employer. Savings in the third pillar pension plans are taxdeductible to take advantage of the same tax treatment as in the second-pillar pensions. Collecting benefits during retirement is taxed and pay-out is only allowed in the form of an annuity.

\section{$4 \quad$ Data and study design}

Our survey was fielded among the members of the CentERpanel. This panel is representative of the Dutch population and answers on a recurring basis questions mainly related to their broad financial situation (e.g. income, wealth holdings, pensions but also expectations on income, etc...) and some psychological questions, perceptions of risk for example. These data, known as the DHS (DNB Household Survey) are available for academic research. ${ }^{8}$ Our survey was put forward to 2,840 household members that are 16 years or older. 1,845 took part in the survey, giving a response rate of 65\%. Data collection took place from 11th - 15th of May 2012. Main background characteristics of the respondents are given in appendix A. The appendix also shows the background characteristics of all members of the CentERpanel. Overall, non-response does not seem to be related to observable characteristics. We do find a lower response rate for young individuals in particular, which is a common feature in surveys on retirement. To account for this the descriptive statistics in this paper have been weighted with regard to age, gender, education and individual yearly income to obtain a representative view of the Dutch population. As we are especially interested in future retirement behavior, we will restrict the analysis to respondents younger than 65 years who are not retired and completed the whole survey. This leaves us with a sample size of 1,113 respondents.

The first part or our survey examines whether the social environment of respondents influences their retirement age decisions and which persons in the social environment are most relevant in this decision. The first set of questions is asked to the respondents who currently work or have worked before. We start asking the respondents who is likely to provide them with retirement advice:

${ }^{8}$ For more information, see http://www.centerdata.nl/en. 
What persons do you expect to give you advice when to retire?

$$
\text { Not at all Some Certainly }
$$

Spouse

Children

Friends

Family

Coworkers

Neighbors

Financial advisor / pension fund

Advice may take different forms: it can be actively sought for hiring a financial advisor but it can also be casually given by for example a lunch with coworkers. The latter unsolicited advice may be less meaningful for the respondents than advice and information they have asked for themselves. More in general, advice and information may have more value depending on the source. To explore the relevance of advice, respondents who indicate to receive advice are asked how much weight they attach to this advice.

In the previous question we asked you which persons give you advice. What weight do you attach to the advice of the following persons?

Spouse

$$
\text { None Alittle Some Much }
$$

Children

Friends

Family

Coworkers

Neighbors

Financial advisor / pension fund

The impact of the social environment can go beyond giving advice and providing information Individuals may take the personal situation of other people in their social environment into account. In particular, we ask

Of what persons do you take the personal situation into account for your decision when to retire?

Spouse

$$
\text { Not at all A little Somewhat certainly }
$$

Children

Friends

Family

Coworkers

Neighbors

The second part of the survey studies the response to changes in the retirement age of the social environment using vignettes. This enables the identification of a causal effect as we vary the behavior of the social environment exogenously and investigate the change in the retirement age of the respondent in a controlled environment. The possible concern about external validity is alleviated by letting the respondent answer the questions for a fictive person. In this way, respondents abstract from their personal situation. Van Beek et al. (1997) offer an example of such a study for preferences of employers regarding employees.

Before the respondents answer the vignettes questions, they are given a fictive flexible retirement scheme. This scheme emphasizes the availability of choice options around a standard retirement age. Earlier take-up leads to lower retirement benefits, and a later take-up yields higher benefits for the remainder of the life-time. The wording of the retirement scheme is as follows (the percentages coincide roughly with actuarial fairness):

Nowadays, policy makers discuss a new retirement scheme. Current plans provide the possibility to decide when to start receiving pension entitlements. If you have worked forty years and retire at the standard retirement age, the pension entitlements (including state pensions) equal 70\% of average gross income. The standard retirement age is at this moment 65 years. Retiring a year before the standard retirement age implies approximately 7\% 
less pension entitlements per month for the remainder of your life. Retiring a year after the standard retirement age implies an increase of approximately $7 \%$ in pension entitlements.

The vignettes involve a fictive person, who is faced with the question how to adjust her/his retirement age. At the moment that retirement is still far away, this person has a planned retirement age. Later once the person turns older, it appears that the typical age of retirement of individuals in her or his social environment has changed. The respondent is then asked to evaluate whether she/he would change the retirement planning being the vignette person. Below, we provide an example:

John (or Lisa) is not yet eligible for retiring. He (or she) does think about it from time to time. John plans to retire at 65 years of age considering this retirement scheme. At this time many of his older coworkers (or friends and family members) retire at 65 years of age. When John turned 60 years old, most coworkers retire at 66 years of age. This is a consequence of people experiencing longer and healthier lives. What would you do in the situation of John?

$1 \quad$ Retire before 65 years of age

$2 \quad$ Retire at 65 years of age

3 Retire at 65.5 years of age

$4 \quad$ Retire at 66 years of age

$5 \quad$ Retire at 66.5 years of age

$6 \quad$ Retire at 67 years of age

$7 \quad$ Retire after 67 years of age

The questions are designed to elicit variation both within and between respondents. Between respondents the vignettes differ in the gender of the vignette person (male or female), the nature of the social environment (friends and family or colleagues), the reason for other individuals to adjust their retirement age (individuals living longer and healthier lives (given in preceding example), more need for experienced workers by employers, longer working due to the financial consequences of the economic crisis, and a one year increase in the statutory standard retirement age). Out of the four different reasons, only one reason induces financial incentives in terms of a change in the available retirement schemes (the increase in the standard retirement age).

The within respondent variation, follows from asking each respondent four vignettes. These vignettes vary the retirement ages of the vignette person and the social environment. Table 2 provides the different variations. Appendix B lists all questions.

Table 2 The different retirement ages in the vignettes

\begin{tabular}{|l|c|c|c|}
\hline & $\begin{array}{l}\text { Original retirement age } \\
\text { plan of vignette person }\end{array}$ & $\begin{array}{l}\text { Original retirement age } \\
\text { of social environment }\end{array}$ & $\begin{array}{l}\text { New retirement age of } \\
\text { social environment }\end{array}$ \\
\hline & & & $\mathbf{6 5}$ \\
\hline Vignette 1 & $\mathbf{6 5}$ & $\mathbf{6 5}$ & $\mathbf{6 6}$ \\
\hline Vignette 2 & $\mathbf{6 5}$ & $\mathbf{6 5}$ & $\mathbf{6 7}$ \\
\hline Vignette 3 & $\mathbf{6 4}$ & $\mathbf{6 4}$ & $\mathbf{6 6}$ \\
\hline Vignette 4 & $\mathbf{6 4}$ & $\mathbf{6 5}$ \\
\hline
\end{tabular}




\section{$5 \quad$ Empirical results}

\subsection{Advice and the personal situation of the social environment}

We first explore the role of advice given by different groups in the social environment. As potential advisors, we distinguish the spouse, children, friends, family, coworkers, neighbors and the professional financial advisor.

The answers by our respondents show that the propensity to give advice varies among the advisors as well as the impact on the planned retirement behavior (Figure 1). Approximately $90 \%$ of the non-retired respondents indicate that they discuss retirement plans with their spouse. Around $90 \%$ of this group states they attach some or much weight to this advice. Looking at the subgroup of the respondents that are cohabiting (married or unmarried) $97 \%$ indicate to receive advice from their spouse and only $7 \%$ state that they attach none or little weight to the advice from their spouse. ${ }^{9}$

Children, friends, family, coworkers and the financial advisor or pension fund are also important in retirement decision making: around $60 \%$ of the respondents indicate to receive advice from these groups. In particular the advice from children and the financial advisor is viewed as important: around $60 \%$ of the respondents attach some or much weight to their advice. ${ }^{10}$ The advice of friends, family and coworkers is somewhat less important as respondents give it less weight. Advice from neighbors, who are typically neither experts nor very closely related to the respondents, is relatively unimportant.

Figure 1: Influence and importance of different groups in the social environment on retirement plans

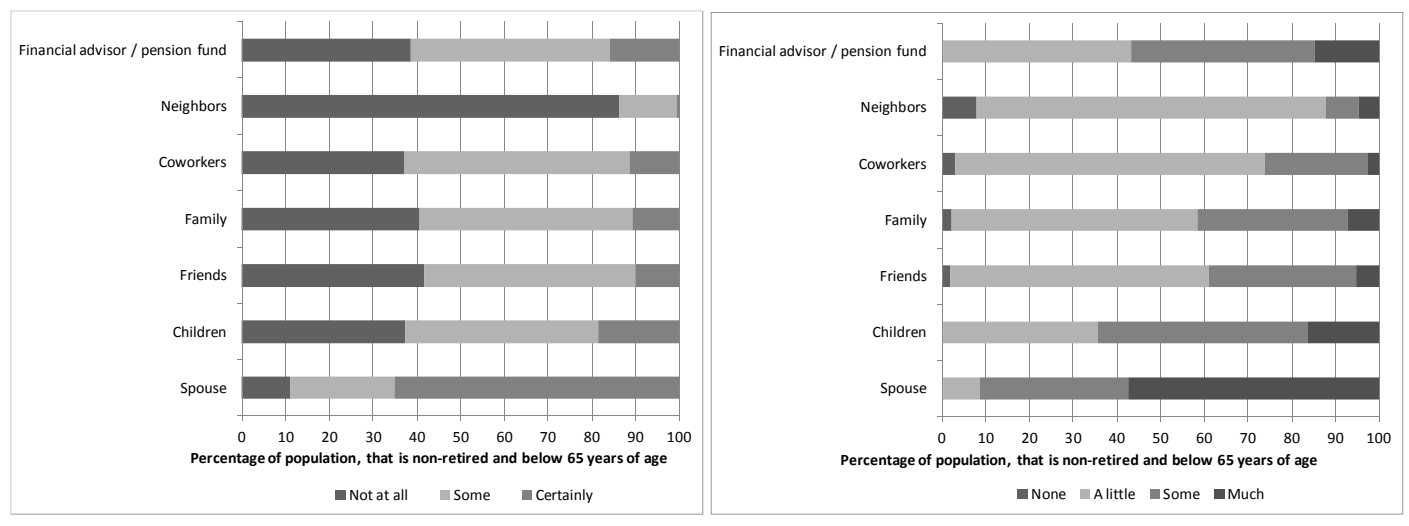

Which persons do you expect to provide you with retirement advice? (Left) Which weight do you attach to the advice of the following persons? (Right)

The role of the social environment is not limited to giving advice, as the utility that individuals derive from work or retirement is not independent from the situation of the social environment. Coile (2004) finds that $62 \%$ of men who are to retire in the near future, look forward to retirement only if the partner will retire as well. Schirle (2008) finds that the increased labor force participation of older married males can be explained from the increased female labor force participation. These studies show that leisure apparently has more value when it can be enjoyed with other members of the household. Indeed, our results show that the personal situation of the partner is very important for retirement decisions (Figure 2). More than $80 \%$ take the personal situation of the spouse at least somewhat into consideration ${ }^{11}$, and more than $50 \%$ most certainly. More than $40 \%$ of the respondents take the personal situation of the children into account. The personal situation of others is less important. Nonetheless, the personal situation of family, friends and coworkers is still given little consideration by 40 to $50 \%$ of the respondents. For coworkers, it is less likely that this preference is related to the enjoyment of joint leisure. But culture or social norms at the work place may play a role. The fact that Dutch pension schemes are mostly organized at the company or the sector level could contribute to this.

\footnotetext{
${ }^{9}$ For respondents that do not cohabit currently, the number that expects to receive advice from a partner when nearing retirement is $62 \%$, while $19 \%$ attach little or no weight to this advice.

${ }^{10}$ The impact of having children does not vary substantially with the age of the respondent.

11 This number varies substantially between respondents that do (98\%) and do not cohabit (64\%).
} 
Figure 2: Taking the personal situation of other people into account in planning for retirement

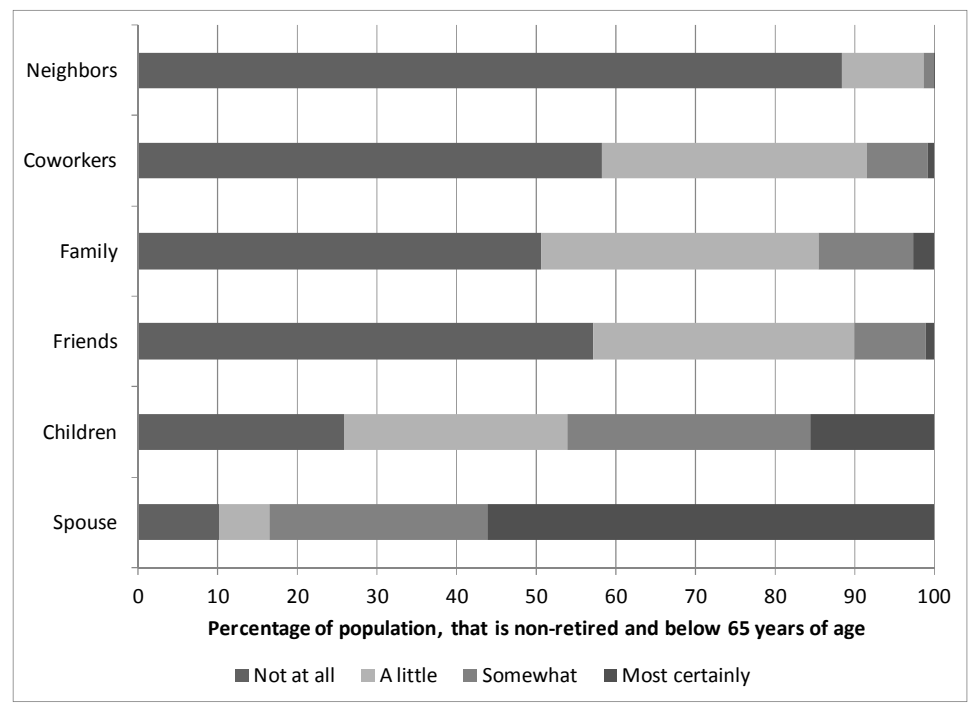

Do you take the personal situations of these persons into account in deciding when to retire?

\subsection{The retirement age of the social environment}

The social environment does not only give advice, but sets an example by their retirement decisions as well. We examine this relation using vignette questions (introduced in Section 4). Recall that respondents indicate how they would decide in the case of a fictive person faced with a hypothetical situation in which the social environment changes its retirement behavior. As the retirement age of the social environment increases from 65 to 66 years, almost $35 \%$ of the respondents indicate to retire at 66 years as well (Figure 3 , left panel). ${ }^{12}$ In case the increased retirement age of the social environment is 67 years, more than $25 \%$ of the respondents retire at 67. Interestingly, the number of respondents indicating to retire at 66 drops substantially to less than $20 \%$. As the only difference between these two vignettes is whether the social environment increases its retirement age to 66 or 67 , the different answers show that the retirement behavior of the social environment does matter for decisions on the individual retirement age.

Regardless of the new retirement age, between $35 \%$ and $45 \%$ of respondents indicate that they will retire at 65 , the original planned retirement age in both vignette questions. This group does not seem sensitive to the change in retirement age by the social environment. The decision to stick to the original retirement age plan is expected in a framework that puts financial incentives central in decision making as financial incentives have not changed. ${ }^{13}$ An alternative explanation for the choice to stick to 65 is that this particular age constitutes a reference point in retirement decision making. Since the introduction of state pensions in the Netherlands in 1957 until 2013, the statutory retirement age was equal to 65. To explore the relevance of both explanation, we compare the answers to vignette questions 1 and 3 (Figure 3, right panel). Vignette 3 is based on a planned retirement age of 64 and an increased retirement age for the social environment of 65 (compared to 65 respectively 66 in vignette 1). $45 \%$ of respondents retire at 65 when this is the new retirement age of the social environment and 64 is the original planned retirement age. This is more than the $33 \%$ when the original retirement age is increased from 65 to 66 . At the same time, 29\% sticks to the 64 retirement plan (versus $42 \%$ when the original plan is 65). Thus one third of respondents in vignette 1 stick to 65 because it is an important reference point in the current retirement practice and two third of this group seems to be insensitive to the retirement behavior of the social environment.

\footnotetext{
12 Vignette 3 is not shown in Figure 3, but is presented as a robustness check at the end of the section.

13 This is true for at least for $75 \%$ of the respondents. Recall that the reasons varied between respondents and one of the four reasons does include a financial incentive as it mentions that the pension scheme would be less generous.
} 
Figure 3: The impact of changes in the retirement age of the social environment
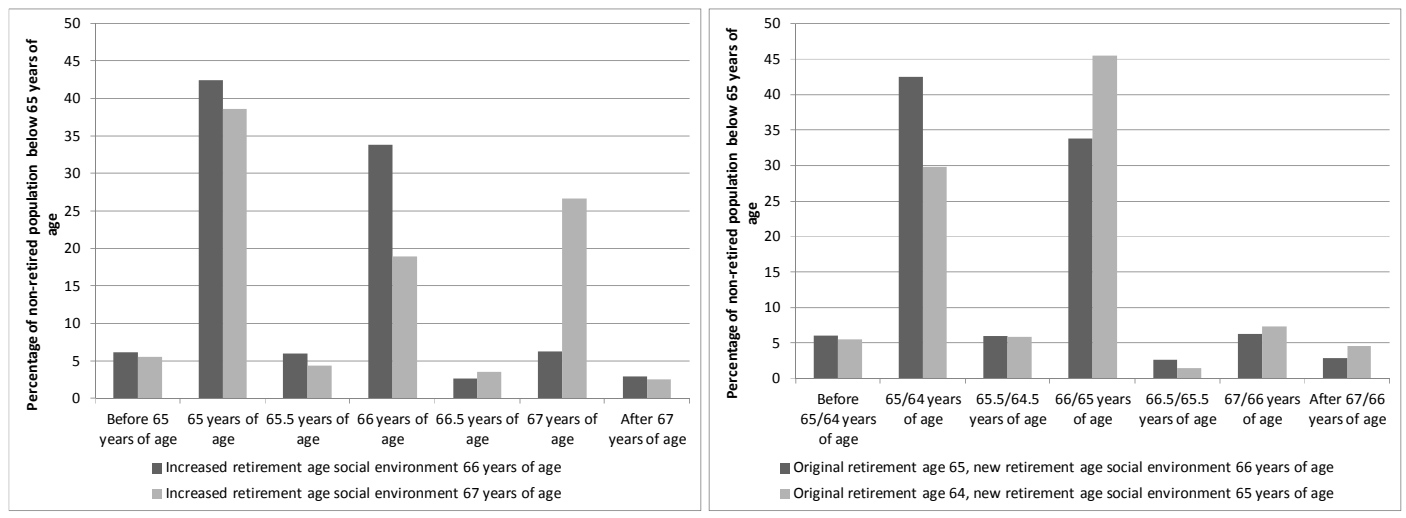

The left panel compares different increases in the retirement age. One question increases the retirement age of the social environment to 66 , while the other question increases the retirement age to 67 . The right panel compares a shift in all retirement ages with one year. See vignettes 1,2 and 4 in Table 2.

To better understand the role of behavior of the social environment for respondents, we examine the vignette responses for a number of important characteristics of the respondents. The age of the respondents matters for their reaction to a change in the retirement behavior of the social environment. Figure 4 shows that respondents aged between 55 and 64 more often stick to retirement at 65 in comparison to younger age groups, irrespective whether this is the original or the increased retirement age of the social environment. Thus the special role of 65 in retirement decisions seems more important for older respondents for who 65 has been the official retirement age for almost their whole working career.

Figure 4: Respondents aged between 55 and 64 focus on retirement age of 65
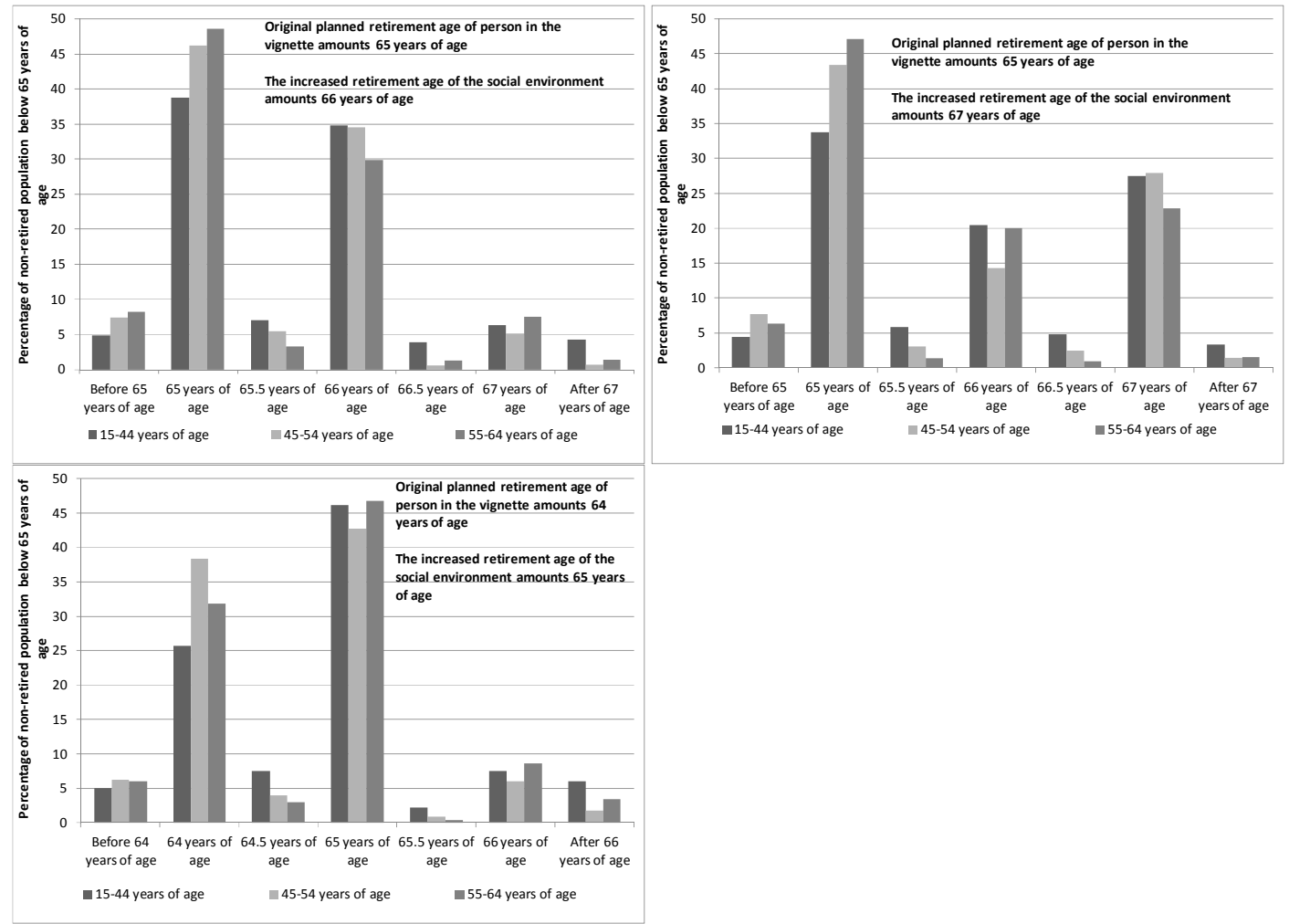

The figure shows the comparison over age when the social environment increases their retirement age to 66 (top left panel, vignette 1), or to 67 (top right panel, vignette 2) and when the original retirement age is 64 (bottom panel, vignette 4). The vignette numbers refer to Table 2. 
Respondents from households with net household income in two middle income classes follow the increased retirement age of the social environment more closely than respondents from lower or higher income households who rather prefer the original plan with a lower retirement age (Figure 5). Higher income households can more easily afford retirement at an earlier age. Lower income households may have a stronger preference for earlier retirement because they are in worse health and working in more demanding professions. ${ }^{14}$

Figure 5: Lower income households more attached to retirement at $\mathbf{6 5}$
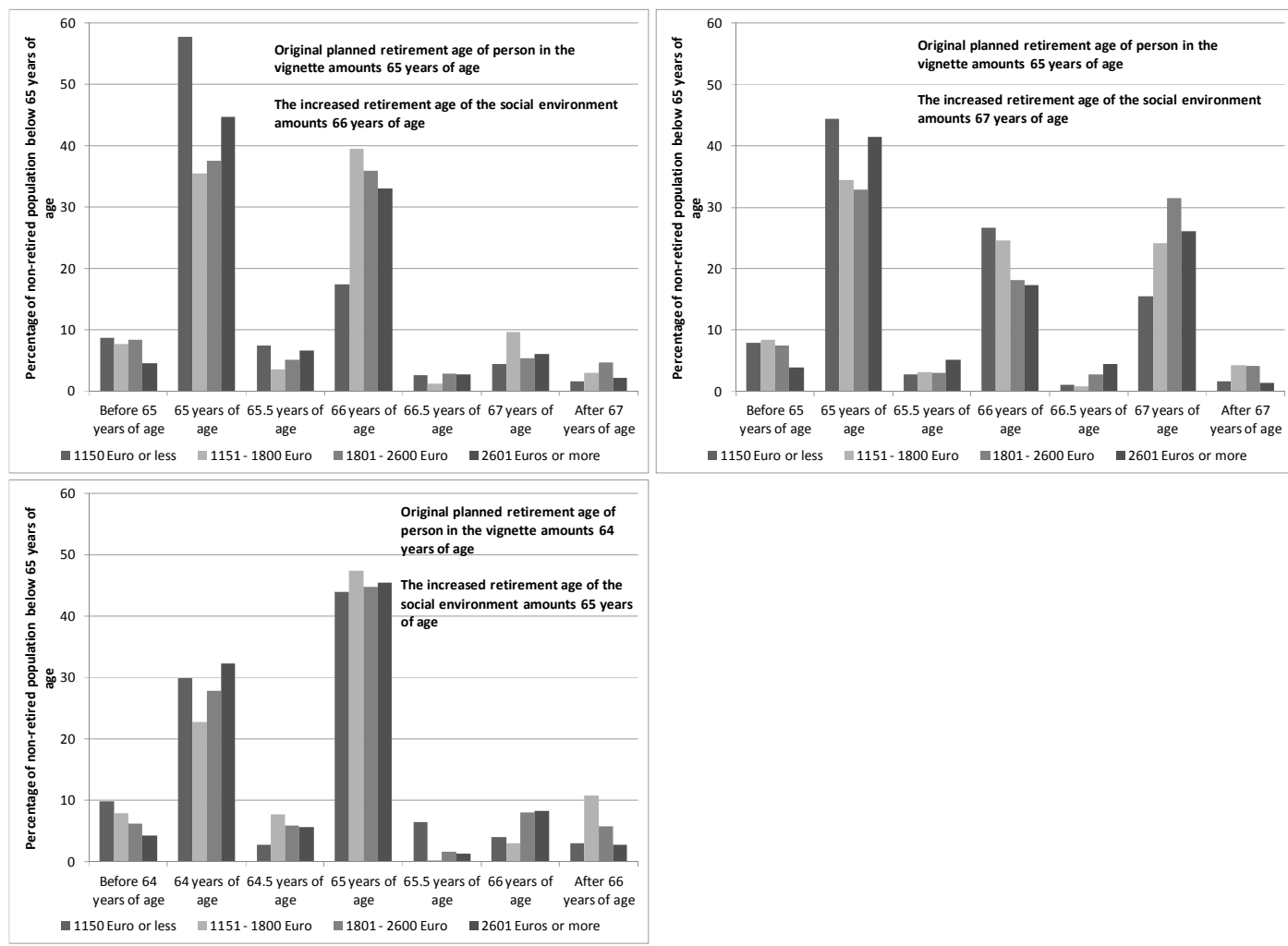

The figure shows the comparison over net household income when the social environment increases their retirement age to 66 (top left panel, vignette 1), or to 67 (top right panel, vignette 2) and when the original retirement age is 64 (bottom panel, vignette 4). The vignette numbers refer to Table 2 .

Higher educated individuals follow the increased retirement age of the social environment most closely (Figure 6). $35 \%$ to $50 \%$ of the respondents with the highest, tertiary education degree follow the increased retirement age of the social environment. A possible explanation is that they show a faster adaptation to changing circumstances. ${ }^{15}$ Respondents with lower secondary education stay closer to the age of 65 disregarding whether it is the original planned retirement age or the increased age of the social environment, suggesting that in particular among this subgroup the age of 65 is an important anchor in retirement decisions.

\footnotetext{
${ }^{14}$ Life expectancy is lower among low income individuals (see for instance Kalwij et al., 2013).

${ }^{15}$ We have investigated whether there is a direct connection with job satisfaction, but higher educated respondents are as happy with their job as other respondents.
} 
Figure 6: Higher educated individuals most closely follow an increased in retirement age in the social environment
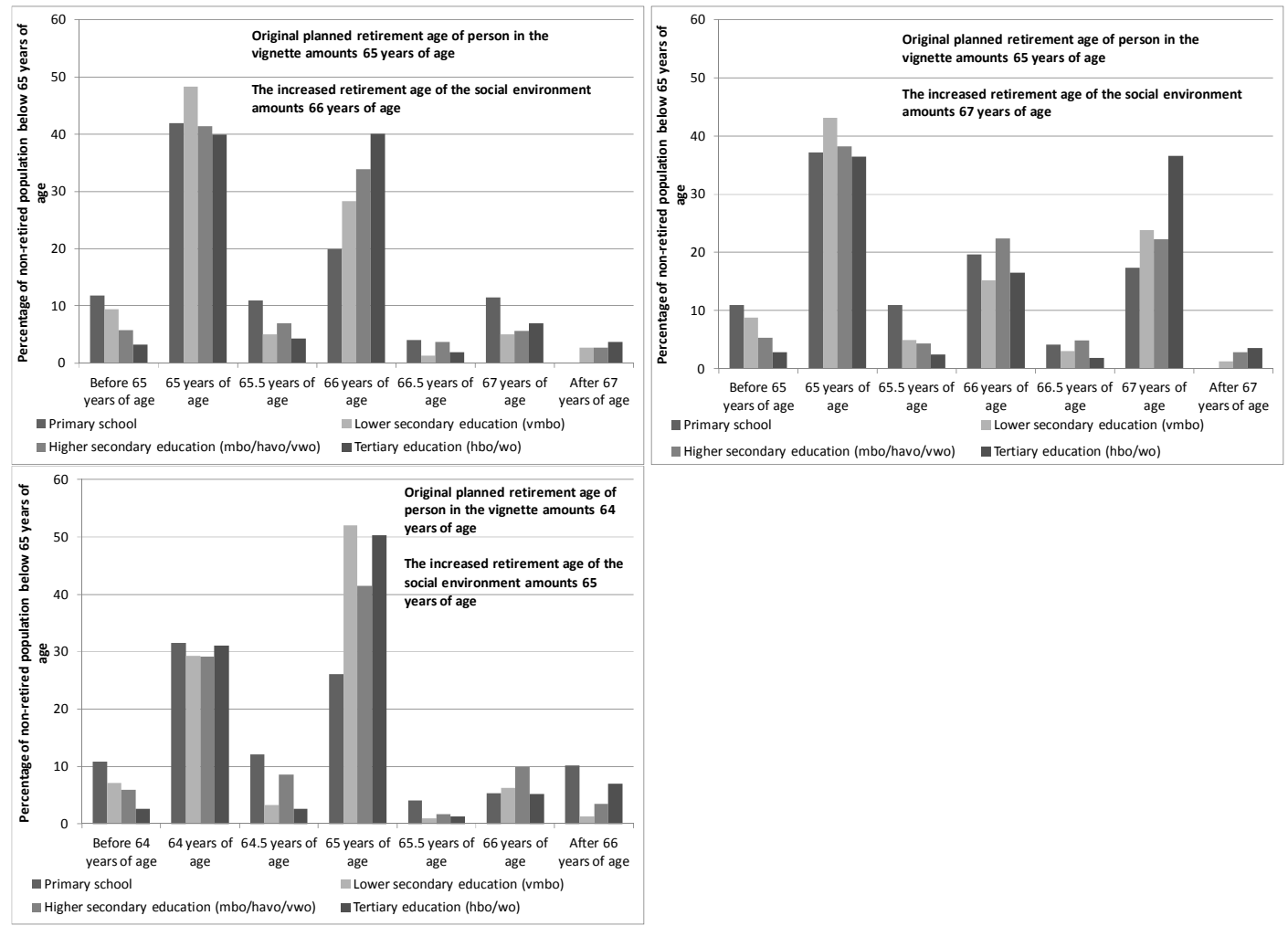

- Tertiary education (hbo/wo)

The figure shows the comparison over education level when the social environment increases their retirement age to 66 (top left panel, vignette 1), or to 67 (top right panel, vignette 2) and when the original retirement age is 64 (bottom panel, vignette 4). The numbers of the vignettes refer to Table 2 .

All in all, the results show that the retirement age of the social environment matters for decisions on the individual retirement age. In particular, the influence of the social environment is heterogeneous among subgroups of respondents. Higher educated, middle income and younger individuals seem to be affected most by the social environment.

\subsection{Modeling and empirical estimates}

The previous analysis has documented the impact of the retirement age of the social environment qualitatively.

Below, we provide estimates for the size of the influence of changes in the retirement age of the social environment. For this purpose, we first introduce a model exploiting that every respondent answers all four vignettes. The dependent variable $y$ is the preferred retirement age in the vignette questions. The respondents answer on a seven-point scale ranging from 'before 65 years of age' to 'older than 67 years of age' in the case of the first vignette. Respondent $i$ answers vignette $l(l=1, \ldots, 4)$ on the answer scale $(j=1, \ldots, 7)$ as follows:

$$
\begin{aligned}
& y_{i}^{l *}=\vartheta^{l}+\delta F_{i}+\varepsilon_{i}^{l} \\
& y_{i}^{l}=j \text { if } \tau_{i}^{j-1}<y_{i}^{l *} \leq \tau_{i}^{j} \text { with } 1 \leq j \leq 7 \\
& \text { with } \tau_{i}^{0}=-\infty \text { and } \tau_{i}^{7}=\infty
\end{aligned}
$$


The latent answer $y_{i}^{l *}$ depends on a vignette specific constant $\vartheta^{l}$ and question characteristics $F_{i}$. ${ }^{16}$ The vignette specific constant captures the age-specifics of each vignette (i.e. the original plan for the retirement age and the change in retirement age of the social environment). The question characteristics only vary between and not within respondents. In particular, three question characteristics vary between respondents: the gender of the person in the vignette, the reason the social environment increases their retirement age, and whether the social environment is termed in 'friends and family' or 'coworkers'. Finally, $\varepsilon_{i}^{l}$ presents an idiosyncratic error term. For identification purposes the error term is assumed to be standard normally distributed $N(0,1)$.

Individual background characteristics are likely to influence the respondents' evaluation of the different vignettes. Therefore, we allow the thresholds $\tau$ to vary over the respondents. The thresholds differ in both observable and unobservable characteristics. For instance, younger individuals may be more inclined to follow the retirement age of the social environment. Ceteris paribus, this would mean their thresholds are lower in comparison to older individuals. The thresholds are modelled in the following way:

$$
\begin{aligned}
& \tau_{i}^{1}=X_{i} \beta_{1}+\zeta_{i} \\
& \tau_{i}^{j}=\tau_{i}^{j-1}+e^{X_{i} \beta_{j}} \text { for } j=2,3,4,5 \text { and } 6
\end{aligned}
$$

In these equations $X_{i}$ are the respondents' observable characteristics. These include gender, age, age squared, household income, education, employment status, region of the Netherlands, home ownership and financial literacy. Our literacy measure is based on three benchmark questions used in the financial literacy literature (Lusardi and Mitchell, 2011). ${ }^{17}$ Unobservable characteristics are denoted by $\zeta_{i}$. The unobservable characteristics only influence the individual-specific threshold level and not the difference between thresholds. Respondents can have a tendency to consistently give low or high answers due to unobserved factors, like the motivation in answering the survey, the health situation or the expected retirement age of the respondent. The term $\zeta_{i}$ captures this unobserved heterogeneity. The unobservable characteristics are assumed to be uncorrelated with the observable characteristics. This model is based on the literature about vignette estimations (Van Soest et al., 2012). The exp-function ensures that the differences between thresholds are positive.

Combining equations (1) and (2) gives:

$$
y_{i}^{l}=j \text { if } \tau_{i}^{j-1}<\vartheta^{l}+\delta F_{i}^{l}+\varepsilon_{i}^{l} \leq \tau_{i}^{j} \text { with } 1 \leq j \leq 7
$$

The unobserved heterogeneity $\zeta_{i}$ is assumed to be drawn from a normal distribution. Therefore, we can write the individual contribution to the maximum likelihood function as follows:

$$
L_{i}=\int_{-\infty}^{\infty} \prod_{l=1}^{4} P\left(Y_{i}^{l}=y_{i}^{l} \mid \zeta_{i}\right) \frac{1}{\sigma_{\zeta}} \varphi\left(\frac{\zeta_{i}}{\sigma_{\zeta}}\right) d \zeta_{i}
$$

The probabilities are calculated for given $\tau_{y_{i}^{l}}$ as:

$$
\begin{gathered}
P\left(Y_{i}^{l}=y_{i}^{l} \mid \zeta_{i}\right)=\Phi\left(\tau_{y_{i}^{l}}\left(\zeta_{i}\right)-\vartheta^{l}-\delta F_{i}^{l}\right)-\Phi\left(\tau_{y_{i}^{l}-1}\left(\zeta_{i}\right)-\vartheta^{l}-\delta F_{i}^{l}\right) \\
\text { for } 1 \leq y_{i}^{l} \leq 7
\end{gathered}
$$

Table 3 shows the coefficient estimates for the differences in question and vignette characteristics. Table 4 reports how these coefficient estimates can be translated in an estimated effect on the retirement age. ${ }^{18}$ The

\footnotetext{
${ }^{16}$ Notice that the coefficient of the question characteristics does not vary across vignettes but between respondents only. Appendix C lists the estimation results for each vignette separately and shows that these coefficients do not vary much among vignettes. Moreover, note that this model is nested in a larger model in which these coefficients vary across the vignettes. We have run a LR-test between the two models which indicates that the constraints on the coefficients are not restrictive.

17 The distribution of individual characteristics and the financial literacy questions is listed in appendix A.

18 The estimated model provides us with a predicted probability for each of the 7 answers corresponding to retirement at a particular age. This probability distribution enables us to calculate the expected change in retirement once we attach a numerical value for this change to
} 
threshold estimation results are listed in appendix D. The model is estimated using simulated maximum likelihood. The unobserved heterogeneity is approximated by drawing 50 times from a standard normal distribution and using Halton draws. ${ }^{19}$ The negative sign for gender in Tables 3 and 4 indicates that the stated retirement age for female vignette persons is smaller than for male vignette persons, but the difference is not statistically significant (at the 5\% level). Changes in retirement behavior of friends and family compared to retirement behavior of coworkers influence respondents less. If the social environment consists of coworkers instead of friends individuals report an extra increase in their retirement age of somewhat more than 1 month. Furthermore, the likelihood of later retirement increases with reasons being more 'financial'. The reason with a cut in benefits elicits the strongest response. A reduction of pension rights equal to one year of benefits leads to a delay in retirement of somewhat more than two months. The reason 'Consequences of the financial crisis' which the respondent may interpret as a financial incentive that applies to his situation as well leads to a comparably higher retirement age.

The baseline vignette involves an original planned retirement age of 65 years and an increase of the retirement age of the social environment to 66 . Thus, the average respondent indicates to retire when the social environment retires one year later at 67 (Table 3). Furthermore, an increase with one year from an original planned retirement age of 64 to 65 by the social environment, has a larger effect on the planned retirement age of the respondent than the same increase from 65 to 66 . This highlights the special role of the age of 65 in retirement decisions.

Individuals postpone retirement on average three months when the social environment increase their retirement age with one year. This result is obtained by comparing the individual retirement ages in the case the retirement age of the social environment increases from 65 to 66 with case in which the retirement age increases from 65 to 67 (Table 4). This response to changes in the retirement age of the social environment is quite sizeable when compared to other estimates from the literature. Mastrobuoni (2009), for instance, finds an increase of 6 months in response to an increase in the US Normal Retirement age of one year. Our results suggest that social interactions could explain a substantial part of this increase.

Table 4 shows that respondents postpone retirement with an additional two months when the retirement age of the social environment increases from 64 to 65 compared to an increase from 65 to 66 . In both cases the difference in retirement age of the social environment is one year but nevertheless respondents retire later in the latter case. This could be related to the special role of the age of 65 being the statutory retirement age in the Netherlands for over half of a century.

each answer option. The attached values indicate the difference between the retirement age corresponding to the answer option and the original retirement age. For instance, the answer option ' 66.5 years of age' was assigned the value 1.5 for questions where the original retirement age is 65 . Table 4 shows the resulting expected change in retirement age given a change in question or vignette characteristics. For instance, the difference between a male and female vignette name is the difference in expected change in retirement age between having a male and a female vignette name respectively. The standard errors of these estimates are based upon bootstrapping with 200 replications.

${ }^{19}$ For Halton draws mdraws is used (Cappellari and Jenkins, 2006). We have verified that a higher number of draws does not affect the results. Alternatively, the integral can be numerically approximated with a Riemann sum. We calculated this with an upper (lower) bound of (-) 10 and a number of intervals equal to 2000 . The result is very similar to the simulation with Halton draws. 
Table 3 Model estimates for the effect of question and vignette characteristics on the retirement age

\begin{tabular}{|c|c|c|}
\hline \multirow{2}{*}{ Gender vignette person ( = 1 if female) } & \multicolumn{2}{c|}{ Retirement age } \\
\cline { 2 - 3 } & Coefficient & Standard error \\
\hline Composition social environment ( = 1 if 'Friends and family') & -0.0317 & 0.1354 \\
\hline More need for experienced employees & 0.1075 & 0.1349 \\
\hline Financial consequences of the economic crisis & $0.4318^{* *}$ & 0.1986 \\
\hline Reduction of pension rights by one year & $0.5042^{* * *}$ & 0.1898 \\
\hline$\theta^{2}($ Social environment increases retirement age from 65 to 67$)$ & $0.7270^{* * *}$ & 0.0569 \\
\hline$\theta^{3}$ (Planned retirement age of vignette person amounts 64) & $1.2185^{* * *}$ & 0.0591 \\
\hline$\theta^{4}($ Social environment increases retirement age from 64 to 65) & $0.5723^{* * *}$ & 0.0559 \\
\hline Log likelihood & \multicolumn{2}{|c|}{11766} \\
\hline Number of respondents & \multicolumn{2}{|c|}{0} \\
\hline
\end{tabular}

Dependent variable is the new retirement age (in the answer categories 1-7 where, for instance, 2 coincides with an unchanged retirement age compared to the initial plan of the fictive person and 4 by an increase of one year). *** Statistical significance at 1\%, ** Statistical significance at $5 \%, *$ Statistical significance at $10 \%$. The baseline vignette has a male vignette person, coworkers as reference group and as reason to postpone retirement that 'people live longer and healthier lives'. The reference vignette involves an increase in the retirement behavior of the social environment from 65 to 66 and an original planned retirement age of 65 .

Table 4 Magnitude of question and vignette effects on average retirement age

\begin{tabular}{|l|c|c|}
\hline & \multicolumn{2}{l|}{ Effect on average retirement age } \\
\hline & Magnitude & Standard error \\
\hline Question characteristics & & \\
\hline Female vignette name instead of male vignette name & -0.05 & 0.05 \\
\hline Social environment consists of friends instead of coworkers & $-0.11^{* *}$ & 0.05 \\
\hline More need for experienced employees instead of longer and healthier lives & 0.02 & 0.07 \\
\hline $\begin{array}{l}\text { Financial consequences of economic crisis instead of longer and healthier } \\
\text { lives }\end{array}$ & $0.17 * *$ & 0.07 \\
\hline Reduction of pension rights vs. longer and healthier lives & $0.19 * * *$ & 0.07 \\
\hline Different retirement behavior of social environment (differences between vignettes) & \\
\hline $\begin{array}{l}\text { Increase of retirement age of social amounts one year (social environment } \\
\text { increases retirement age from 65 to 67 instead of to 66, Vignette 2 vs. 1) }\end{array}$ & $0.25 * * *$ & 0.02 \\
\hline $\begin{array}{l}\text { Original planned retirement age of vignette person amounts 64 instead of } \\
\text { 65 years of age (Vignette 3 vs. 1) }\end{array}$ & $0.43 * * *$ & 0.02 \\
\hline $\begin{array}{l}\text { One year decrease in all retirement ages (planned retirement ages amount } \\
65 \text { and increased retirement age of social environment amounts 65, } \\
\text { Vignette 4 vs. 1) }\end{array}$ & $0.20^{* * *}$ & \multirow{2}{*}{0.02} \\
\hline
\end{tabular}

Results are obtained with bootstrapping and 200 replications. Larger number of replications does not affect the results. Effects of question characteristics are shown for vignette 1 . But these show little variation over the different vignettes as our model implies. $* * *$ Statistical significance at $1 \%, * *$ Statistical significance at $5 \%, *$ Statistical significance at $10 \%$. Vignette numbers refer to Table 2.

\subsection{Sensitivity analysis}

The vignette results highlight that the retirement age of the social environment is an important determinant for many individuals in planning their retirement age. In this section, we investigate the robustness of our findings. So far, we have considered vignettes in which the planned retirement age of the fictive vignette person and the current retirement age of the social environment coincide. A possible concern is that the respondents interpret this as an implicit signal that the fictive person wants to retire at the same age as the social environment which would bias the results in favor of finding a social environment effect. For that reason, we have included a 
vignette question with different retirement ages (see Table 2, vignette 3). In particular the social environment in this vignette currently retires at age 65, while the fictive vignette person plans an earlier retirement at age 64 .

The effect on the mean retirement age of the individual once the social environment increases is retirement age to 66 in this question is quite large: around 5 months (see Table 4). A catch-up effect seems to be present. Figure 7 illustrates this point further. $25 \%$ of the respondents indicate to retire at 66 when the original retirement ages differ which corresponds to an increase in the planned retirement age of 2 years instead of the increase of 1 year for the social environment. The implication is that individuals are more sensitive to the level of the retirement age of the social environment than to the change in this level, which emphasizes the finding that the retirement age of the social environment of an individual is an important determinant in planning for his or her retirement.

Figure 7 Respondents largely insensitive to original retirement age of fictive person

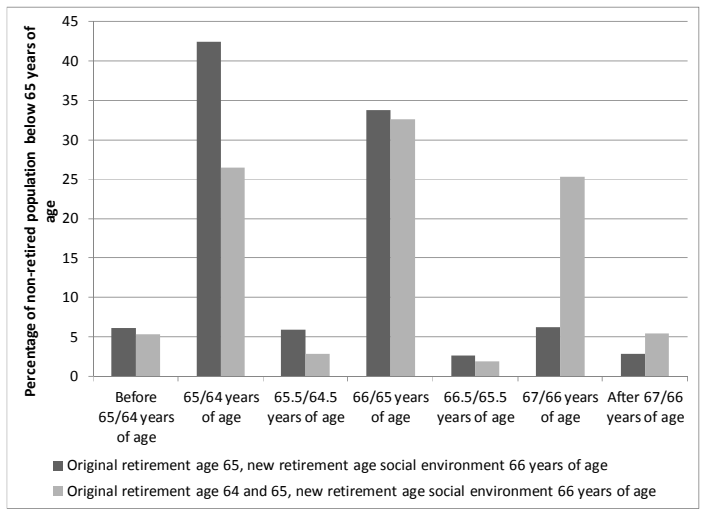

The dark color indicates the answers to the question in which the original retirement age was 65 for both the social environment and the fictive person plan (vignette 1, Table 2). The light color indicates the answers to the question in which the original retirement age differs between the social environment and the fictive person (vignette 3, Table 2). The answer scales differ between these two questions, as in both cases the answer scales begin just before the planned retirement age of the fictive person.

A possible concern is that respondents are not (yet) interested in their retirement and do not have a clear thought on when one should retire. Therefore, we check whether the results are sensitive to the confidence of respondents in their answers. After having answered the four vignette questions, respondents indicate how certain they are of their given answers on a 5 points scale ranging from 'very uncertain' to 'very certain'. Indeed a quarter of the respondents indicate they are ‘very uncertain' or 'uncertain' about their answers. Table 5 (column 2) shows that the results are very similar once these respondents are dropped from the sample. As a consequence of the reduced number of observations, the standard errors are somewhat larger. However, the question specific constants are somewhat larger as well. Thus respondents that are certain of their answers tend to follow the retirement behavior of their social environment more closely. This means that the estimated effects of retirement behavior of the social environment on individual retirement behavior could even be somewhat larger than reported above.

It was noted in the discussion of the sample characteristics that young respondents seem to be underrepresented. Retirement is a distant concept for younger individuals and they are not likely to think much about retirement (Van Rooij et al., 2007). It is not clear how this will affect the results, although the descriptive statistics in Figure 4 show that younger cohorts are more likely to follow changes in the behavior of the social environment than older cohorts nearing the retirement age. Therefore, elder respondents may be less sensitive to the behavior of the social environment. Table 5 (columns 3 and 4) shows however significant results for respondents younger and older than 50 years of age.

Next, we include the expected retirement age of the respondents. In the vignette questions, respondents are asked what they would do being that person given the information provided. A concern is that they have a firm preference for retiring at a certain age and will reveal this preference regardless of the information provided in the vignette question. To test whether this type of behavior is driving our result, we include information on 
when the respondents themselves expect to retire. This information is available for 465 respondents. Table 5 shows that the inclusion of this variable in the threshold estimations leads qualitatively to the same estimates.

Table 5 Sensitivity checks on the most elaborate model

\begin{tabular}{|c|c|c|c|c|c|}
\hline & $\begin{array}{l}\text { Original } \\
\text { model }\end{array}$ & $\begin{array}{l}\text { Restriction to } \\
\text { respondents } \\
\text { that are certain } \\
\text { of their } \\
\text { answers }\end{array}$ & $\begin{array}{l}\text { Respondents } \\
\text { younger than or } \\
\text { equal to } 50 \\
\text { years of age }\end{array}$ & $\begin{array}{l}\text { Respondents } \\
\text { older than } \\
50 \text { years of } \\
\text { age }\end{array}$ & $\begin{array}{l}\text { Inclusion of } \\
\text { the expected } \\
\text { retirement age }\end{array}$ \\
\hline \multirow{2}{*}{$\begin{array}{l}\text { Gender vignette } \\
\text { person } \\
(=1 \text { if female) }\end{array}$} & -0.0317 & $-0.3213^{*}$ & $-0.3405^{*}$ & 0.0832 & 0.0577 \\
\hline & $(0.1354)$ & $(0.1754)$ & (0.1981) & $(0.1959)$ & $(0.1977)$ \\
\hline \multirow{2}{*}{$\begin{array}{l}\text { Composition } \\
\text { social environment } \\
\text { (=1 if 'Friends and } \\
\text { family') }\end{array}$} & $-0.3317 * *$ & -0.2890 & $-0.4847 * *$ & -0.1977 & $-0.3609 *$ \\
\hline & $(0.1349)$ & $(0.1816)$ & $(0.2013)$ & $(0.1990)$ & (0.1949) \\
\hline \multirow{2}{*}{$\begin{array}{l}\text { More need for } \\
\text { experienced } \\
\text { employees }\end{array}$} & 0.1075 & 0.2212 & -0.1922 & 0.0410 & -0.0521 \\
\hline & $(0.1986)$ & $(0.2630)$ & $(0.3036)$ & $(0.2763)$ & $(0.2878)$ \\
\hline \multirow{2}{*}{$\begin{array}{l}\text { Financial } \\
\text { consequences of } \\
\text { the economic } \\
\text { crisis }\end{array}$} & $0.4318 * *$ & $0.7066 * * *$ & $0.5367 *$ & $0.5786 * *$ & 0.3418 \\
\hline & $(0.1912)$ & $(0.2546)$ & $(0.2863)$ & $(0.2831)$ & $(0.2657)$ \\
\hline \multirow{2}{*}{$\begin{array}{l}\text { Reduction of } \\
\text { pension rights by } \\
\text { one year }\end{array}$} & $0.5042 * * *$ & $0.9783 * * *$ & 0.4074 & $0.4889 *$ & $0.7872 * * *$ \\
\hline & (0.1898) & $(0.2526)$ & $(0.2882)$ & $(0.2623)$ & $(0.2766)$ \\
\hline \multirow{2}{*}{$\begin{array}{l}\theta^{2}(\text { Social } \\
\text { environment } \\
\text { increases } \\
\text { retirement age } \\
\text { from } 65 \text { to } 67)\end{array}$} & $0.7270 * * *$ & $0.7336 * * *$ & $0.8625 * * *$ & $0.6101 * * *$ & $0.6864 * * *$ \\
\hline & $(0.0569)$ & $(0.0688)$ & $(0.0809)$ & $(0.0823)$ & $(0.0882)$ \\
\hline \multirow{2}{*}{$\begin{array}{l}\theta^{3}(\text { Planned } \\
\text { retirement age of } \\
\text { vignette person } \\
\text { amounts } 64)\end{array}$} & $1.2185 * * *$ & $1.3256^{* * * *}$ & $1.1486 * * *$ & $1.3519 * * *$ & $1.1984 * * *$ \\
\hline & $(0.0591)$ & $(0.0722)$ & $(0.0827)$ & $(0.0873)$ & $(0.0916)$ \\
\hline \multirow{2}{*}{$\begin{array}{l}\theta^{4} \text { (Social } \\
\text { environment } \\
\text { increases } \\
\text { retirement age } \\
\text { from } 64 \text { to } 65 \text { ) }\end{array}$} & $0.5723 * * *$ & $0.6745^{* * *}$ & $0.4797 * * *$ & $0.6845^{* * *}$ & $0.5338 * * *$ \\
\hline & $(0.0559)$ & $(0.0678)$ & $(0.0785)$ & $(0.0820)$ & $(0.0865)$ \\
\hline Log likelihood & -4766 & -3385 & -2431 & -2231 & -1908 \\
\hline $\begin{array}{l}\text { Number of } \\
\text { respondents }\end{array}$ & 1113 & 833 & 578 & 535 & 465 \\
\hline
\end{tabular}

Dependent variable is the retirement age in the answer categories $1, \ldots, 7$ where, for instance, 2 coincides with an unchanged retirement age compared to the initial plan of the fictive person and 4 by an increase of one year. Standard errors in parentheses $* * *$ Statistical significance at $1 \%, * *$ Statistical significance at $5 \%$, * Statistical significance at $10 \%$, the baseline vignette has a male vignette person, coworkers as reference group and as reason that 'people live longer and healthier lives'. The reference vignette involves an increase in the retirement behavior of the social environment from 65 to 66 years of age and an original planned retirement age of 65 years. The first column with results presents the estimates from Table 3. The estimates in the second column are based on a sample without respondents who indicate to be (very) uncertain about their given answers. The estimates in the third column are based on a sample with solely respondents younger than or equal to 50 years of age. The fourth column presents the results for the sample with respondents older than 50 years of age. The estimates in the fourth column are based on the same sample as Table 3 but includes the actual expected retirement age of the respondents, if available, to the background characteristics of the threshold equations in the original model with unobserved heterogeneity.

As a final robustness check, we estimate a model with less restrictive assumptions. Equation (3) assumes that impact of the background characteristics is equal for the four different vignettes. We relax this assumption by making the thresholds constant:

$$
\tau_{i}^{1}=c^{1}
$$




$$
\tau_{i}^{j}=\tau_{i}^{j-1}+e^{c^{j}} \text { for } j=2,3,4,5 \text { and } 6
$$

We modify latent variable equation (1) to include observed characteristics and unobserved heterogeneity. Moreover, the coefficients of the question characteristics are allowed to vary over the different vignettes. The modified latent variable equation is as follows:

$$
y_{i}^{l *}=\vartheta^{l}+F_{i} \delta^{l}+X_{i} \beta^{l}+\zeta_{i}+\varepsilon_{i}^{l}
$$

This model is estimated with simulated maximum likelihood with 50 Halton draws. Appendix E lists the estimation results and the results are qualitatively similar to the previous estimation results. ${ }^{20}$ If we calculate the retirement age impact, we find that when the social environment retires one year later, individuals will retire about three months later. The special role of 65 years of age is present again and estimated at two to three months. All in all, the estimation results prove to be robust to alternative samples, covariates and models supporting the finding that the retirement behavior of the social environment feeds into the retirement plans of an individual.

\section{Conclusion}

We examined the relationship between social interactions and retirement behavior using a unique survey data set specifically constructed for this purpose. We find that social interactions matter for the individual retirement decision. Individuals receive advice and information from their friends, spouse, children, other family, coworkers and their financial advisor or pension fund. In addition, individual retirement preferences depend on the personal situation of family, friends, and coworkers.

Vignette experiments show the importance of retirement behavior of the social environment with regard to the retirement age. Model estimates controlling for individual specific thresholds and unobserved individual heterogeneity confirm this result. A first explanation is that the decision to retire is a complex decision that is typically taken once in a lifetime. Individuals learn from other people, including their observed behavior. A second explanation is that individuals have a preference for conforming to the behavior of their environment (Bernheim, 1994). Our results show that respondents are somewhat more sensitive to the retirement age of coworkers than of family and friends. This may be interpreted as a sign of relevance of the second explanation. There may exist common norms for retirement within organizations.

Social interactions may strengthen the effect of financial incentives. The impact of the social environment's retirement behavior is relatively large when it is a consequence of financial conditions. Consequently, policy reforms strengthening financial incentives for later retirement may have an additional participation effect through social interactions.

Based on our empirical estimates, respondents increase their retirement age with three months in response to an increase of the retirement age of the social environment by one year. Mastrobuoni (2009) documents a half year increase in the mean retirement age following a year increase in the statutory retirement age in the US. Our findings suggest that, apart from the financial incentive, a large part of this effect is driven by social interactions.

Respondents stick to the state pension age of 65 more often than to other retirement ages if the social environment's retirement age is raised. Moreover, an increase in the retirement age of the social environment from 64 to 65 years of age elicits a two months larger increase in the individual retirement age than a similar increase from 65 to 66 years of age. This finding points at the presence of a norm for retirement at the state pension age. The statutory retirement age of 65 of the state pension in the Netherlands has remained unchanged over half a century after its introduction in 1957, and may have developed into a social norm. Given that social norms develop slowly, the current reform gradually raising the statutory retirement age will have a long term effect on labor participation exceeding the immediate effect (a social multiplier in terms of Glaeser et al, 2003). The short run effect is associated with the adaptations of the individual to the retirement behavior of the social

${ }^{20}$ The simulation is done in the similar way as before. 
environment. The long run effect is associated with the development of social norms with regard to retirement behavior that has been in place for a long time.

\section{References}

Angelucci, M. and G. De Giorgi, 2009, Indirect Effects of an Aid Program: How do Cash Transfers affect Ineligibles Consumption?, American Economic Review, Vol. 99 No. 1, 486 - 508

Beek, K.W.H. van, C.C. Koopmans and B.M.S. van Praag, 1997, Shopping at the labour market: a real tale of fiction, European Economic Review, 41, 295 - 317

Becker, G., 1991, A Note on Restaurant Pricing and Other Examples of Social Influences on Price, Journal of Political Economy, Vol. 99, No. 5 (Oct. 1991), 1109 - 1116

Behaghel, L. and D. Blau, 2012, Framing Social Security Reform: Behavioral Responses to Changes in the Full Retirement Age, American Economic Journal: Economic Policy, 4 (4), 41 - 67

Bernheim, B.D., 1994, A Theory of Conformity, Journal of Political Economy, Vol. 102, No. 5, 841 - 877

Brown, K. and R. Laschever, 2012, When They're Sixty-Four: Peer Effects and the Timing of Retirement, American Economic Journal: Applied Economics, 4 (3), 90 - 115

Cappellari, L. and S. Jenkins, 2006, Calculation of Multivariate Normal Probabilities by Simulation, with Applications to Maximum Simulated Likelihood Estimation, IZA Discussion Paper No. 2112

Coile, C. and J. Gruber, 2000, Social security and retirement, National Bureau of Economic Research, Working Paper No. 7830

Coile, C., 2004, Retirement incentives and couples' retirement decisions, Topics in economic analysis and policy, 4(1)

Coile, C. and J. Gruber, 2007, Future social security entitlements and the retirement decision, The Review of Economics and Statistics, 89(2), 234 - 246

Corneo, G., 2013, Work norms, social insurance and the allocation of talent, Journal of Public Economics, 107 , $79-92$

Duflo, E. and E. Saez, 2002, Participation and investment decisions in a retirement plan: the influence of colleagues' choices, Journal of Public Economics, 85, 121-148

Erp, F. van, N. Vermeer en D. van Vuuren, 2013, Non-financial determinants of retirement, Netspar Panel Paper 34

Fehr, E., S. Gächter, 2000, Fairness and retaliation: The economics of reciprocity, Journal of Economic perspectives, 14(3), 159-181

Fischer, P. and S. Huddart, 2008, Optimal Contracting with Endogenous Social Norms, American Economic Review, 98(4), 1459 - 1475

Gruber, J. en D. A. Wise, 1999, Social Security and Retirement around the World, University of Chicago Press

Gustman, A. and T. Steinmeier, 1985, The 1983 Social Security Reforms and Labor Supply Adjustments of Older Individuals in the Long Run, Journal of Labor Economics, 3 (2), 237-253

Gustman, A. and T. Steinmeier, 2006, Social Security and Retirement Dynamics, Working Paper 2006 - 121 , Michigan Retirement Research Center 
Gustman, A. and T. Steinmeier, 2013, Effects of Social Security Policies on Benefit Claiming, Retirement and Saving, National Bureau of Economic Research Working Paper Series, Working Paper 19071

Hanel, B. and R. Riphahn, 2012, The timing of retirement - New evidence from Swiss female workers, Labour Economics, 19, 718 - 728

Hanushek, E., J. Kain, J. Markman and S. Rivkin, 2003, Does peer ability affect student achievement?, Journal of applied econometrics, Volume 18 Issue 5, 527 - 544

Kalwij, A. S., R.J. Alessie and M.G. Knoef, 2013, The association between individual income and remaining life expectancy at the age of 65 in the Netherlands, Demography, 50(1), 181-206

Kuhn, P., P. Kooreman, A. Soetevent and A. Kapteyn, 2011, The Effects of Lottery Prizes on Winners and Their Neighbors: Evidence from the Dutch Postcode Lottery, The American Economic Review, 101(5), 2226 2247

Lindbeck, A., S. Nyberg, and J. Weibull, 1999, Social Norms and Economic Incentives in the Welfare State, Quarterly Journal of Economics, 114(1), 1 - 35

Lindbeck, A., S. Nyberg, and J. Weibull, 2003, Social Norms and Welfare State Dynamics, Journal of the European Economic Association, 1(2-3),533 - 542

Lindbeck, A. and S. Nyberg, 2006, Raising children to work hard: altruism, work norms, and social insurance, The Quarterly Journal of Economics, November 2006, 1473 - 1503

Ljunge, M., 2010, Sick of the Welfare State? Sticky Stigma and Demand for Social Insurance, University of Copenhagen

Lumsdaine, R., J. Stock and D. Wise, 1996, Why are retirement rates so high at age 65?, Advances in the Economics of Aging, University of Chicago Press, 61-82.

Lusardi, A. and O. Mitchell, 2011, Financial literacy around the world: an overview, Journal of Pension Economics and Finance, 10(4), 497-508

Manski, C.F., 1993, Identification of Endogenous Social Effects: The Reflection Problem, Review of Economic Studies, 60, 531 - 542

Manski, C.F., 2000, Economic Analysis of Social Interactions, Journal of Economic Perspectives, 14, 115-136.

Mastrobuoni, G., 2009, Labor supply effects of the recent social security benefit cuts: Empirical estimates using cohort discontinuities, Journal of Public Economics, 93, 1224 - 1233

OECD, 2011, Pensions at a Glance 2011: Retirement-income Systems in OECD and G20 Countries, OECD Publishing, http://dx.doi.org/10.1787/pension_glance-2011-en

Rooij, M.C.J. van, A. Lusardi and R.J.M. Alessie, 2011, Financial literacy and retirement planning in the Netherlands, Journal of Economic Psychology, 32, 593-608.

Rooij, M.C.J. van, C.J.M. Kool and H.M. Prast, 2007, Risk-return preferences in the pension domain: are people able to choose?, Journal of Public Economics, 91, 701-722.

Schirle, T., 2008, Why have the labor force participation rates of older men increased since the mid-1990s?, Journal of labor economics, 26(4), $549-594$.

Soest, A. van, T. Andreyeva, A. Kapteyn and J. P. Smith, 2012, Self-Reported Disability and Reference Groups, Investigations in the economics of aging, The University of Chicago Press, page 237 - 266 
Topa, G., 2001, Social Interactions, Local Spillovers and Unemployment, Review of Economic Studies, 68, 261 295 
Appendix A Sample statistics

Table A.1 Descriptive statistics of the (estimation) sample and CentER panel

\begin{tabular}{|c|c|c|c|c|c|}
\hline & \multicolumn{2}{|c|}{ Sample } & \multirow{2}{*}{$\begin{array}{c}\text { CentER panel } \\
\text { Percentage }\end{array}$} & \multicolumn{2}{|c|}{ Estimation sample } \\
\hline & Frequency & Percentage & & Frequency & Percentage \\
\hline \multicolumn{6}{|l|}{ Gender } \\
\hline Male & 1,022 & 55.39 & 49.29 & 564 & 50.67 \\
\hline Female & 823 & 44.61 & 50.71 & 549 & 49.33 \\
\hline \multicolumn{6}{|l|}{ Age (years) } \\
\hline $15-24$ & 50 & 2.71 & 11.51 & 37 & 3.32 \\
\hline $25-34$ & 95 & 5.15 & 7.43 & 84 & 7.55 \\
\hline $35-44$ & 290 & 15.72 & 16.31 & 276 & 24.80 \\
\hline $45-54$ & 355 & 19.24 & 18.14 & 340 & 30.55 \\
\hline $55-64$ & 475 & 25.75 & 21.43 & 376 & 33.78 \\
\hline 65 years and older & 580 & 31.44 & 25.16 & 0 & 0 \\
\hline \multicolumn{6}{|l|}{ Education } \\
\hline Primary education & 87 & 4.73 & 10.77 & 35 & 3.14 \\
\hline $\begin{array}{l}\text { Lower secondary } \\
\text { education (VMBO) }\end{array}$ & 504 & 27.38 & 26.38 & 252 & 22.64 \\
\hline $\begin{array}{l}\text { Upper secondary } \\
\text { education (HAVO/VWO) }\end{array}$ & 236 & 12.82 & 12.00 & 143 & 12.85 \\
\hline Lower vocational (MBO) & 293 & 15.92 & 16.57 & 221 & 19.86 \\
\hline Upper vocational (HBO) & 478 & 25.96 & 22.96 & 295 & 26.50 \\
\hline University (WO) & 243 & 13.20 & 11.31 & 167 & 15.00 \\
\hline \multicolumn{6}{|l|}{$\begin{array}{l}\text { Income (gross primary } \\
\text { income individual) }\end{array}$} \\
\hline Less than 10,000 euro & 342 & 18.54 & 20.25 & 201 & 18.06 \\
\hline $\begin{array}{l}\text { Between } 10,000 \text { and } \\
30,000 \text { euro }\end{array}$ & 636 & 34.47 & 28.13 & 368 & 33.06 \\
\hline $\begin{array}{l}\text { Between } 30,000 \text { and } \\
50,000 \text { euro }\end{array}$ & 563 & 30.51 & 31.54 & 347 & 31.18 \\
\hline More than 50,000 euro & 304 & 16.48 & 20.08 & 197 & 17.70 \\
\hline \multicolumn{6}{|l|}{$\begin{array}{l}\text { Income (Nett monthly } \\
\text { income household) }\end{array}$} \\
\hline 1150 euro or less & 124 & 6.72 & . & 73 & 6.56 \\
\hline $1151-1800$ euro & 276 & 14.96 & . & 152 & 13.66 \\
\hline $1801-2600$ euro & 513 & 27.80 & . & 282 & 25.34 \\
\hline 2601 euro or more & 929 & 50.35 & . & 606 & 54.45 \\
\hline \multicolumn{6}{|l|}{ Employment status } \\
\hline Employed at the moment & 948 & 51.69 & . & 902 & 81.04 \\
\hline $\begin{array}{l}\text { Not working at the } \\
\text { moment, but worked in } \\
\text { the past }\end{array}$ & 225 & 12.27 & . & 211 & 18.96 \\
\hline (Early) retired & 614 & 33.48 & . & 0 & 0 \\
\hline Never worked & 47 & 2.56 & . & 0 & 0 \\
\hline \multicolumn{6}{|l|}{$\begin{array}{l}\text { Region of the } \\
\text { Netherlands }\end{array}$} \\
\hline North & 240 & 13.09 & . & 151 & 13.57 \\
\hline West & 761 & 41.49 & . & 466 & 41.87 \\
\hline East & 390 & 21.26 & . & 249 & 22.37 \\
\hline South & 443 & 24.15 & . & 247 & 22.19 \\
\hline \multicolumn{6}{|l|}{ Home ownership } \\
\hline Home owner & 1,403 & 76.04 & . & 867 & 77.90 \\
\hline Renting home & 438 & 23.74 & . & 246 & 22.10 \\
\hline Sub renting home & 2 & 0.11 & . & 0 & 0 \\
\hline Living for free & 2 & 0.11 & . & 0 & 0 \\
\hline \multicolumn{6}{|l|}{ Compound interest } \\
\hline Correct & 1,615 & 88.54 & . & 999 & 89.76 \\
\hline
\end{tabular}




\begin{tabular}{|c|c|c|c|c|c|}
\hline Incorrect & 112 & 6.14 & . & 66 & 5.94 \\
\hline Do not know & 85 & 4.66 & . & 42 & 3.78 \\
\hline Refuse to answer & 12 & 0.66 & . & 5 & 0.45 \\
\hline \multicolumn{6}{|l|}{ Inflation } \\
\hline Correct & 1,546 & 84.76 & . & 935 & 84.08 \\
\hline Incorrect & 118 & 6.47 & . & 79 & 7.10 \\
\hline Do not know & 147 & 8.06 & . & 92 & 8.27 \\
\hline Refuse to answer & 13 & 0.71 & . & 6 & 0.54 \\
\hline \multicolumn{6}{|l|}{ Stock risk } \\
\hline Correct & 894 & 49.01 & . & 565 & 50.81 \\
\hline Incorrect & 164 & 8.99 & . & 89 & 8.00 \\
\hline Do not know & 750 & 41.12 & . & 448 & 40.29 \\
\hline Refuse to answer & 16 & 0.88 & . & 10 & 0.90 \\
\hline
\end{tabular}

Region of the Netherlands: West $=$ Noord- and Zuid-Holland, Utrecht and Zeeland; North $=$ Groningen, Friesland and Drenthe; East = Overijssel, Flevoland and Gelderland; South $=$ Noord-Brabant and Limburg.

Financial Literacy questions (correct answers bold):

(Compound interest) Suppose you had $\$ 100$ in a savings account and the interest rate was $2 \%$ per year. After 5 years, how much do you think you would have in the account if you left the money to grow?

1) More than \$102 2) Exactly \$102 3) Less than \$102 4) Do not know 5) Refuse to answer

(Inflation) Imagine that the interest rate on your savings account was $1 \%$ per year and inflation was $2 \%$ per year. After 1 year, how much would you be able to buy with the money in this account?

1) More than today 2) Exactly the same 3) Less than today 4) Do not know 5) Refuse to answer

(Stock risk) Please tell me whether this statement is true or false. 'Buying a single company's stock usually provides a safer return than a stock mutual fund'.

1) True 2) False 3) Do not know 4) Refuse to answer 


\section{Appendix B The Survey}

Your retirement timing is an important decision in the course of your life. Various factors influence this decision. In this part of the survey we want to ask you questions about your retirement decision and the role of your social environment in this.

What persons do you expect to give / gave you advice in deciding when to retire?

Spouse

$$
\text { Not at all Somewhat Certainly }
$$

Children

Friends

Family

Coworkers

Neighbours

Financial advisor / pension fund

In the previous question we asked you what persons (will) advise you. What weight do you attach to the advice of the following persons?

If already retired: What weight did you attach to the advice of the following persons?

Spouse

None A little Much Very much

Children

Friends

Family

Coworkers

Neighbours

Financial advisor / pension fund

The personal situation of what persons do / did you take into account when contemplating when to retire?

None A little Much $\quad$ Very much

Spouse

Children

Friends

Family

Coworkers

Neighbours

Among policy makers there is a lot of discussion about reforming the pension scheme.

In the present plans it will be possible to decide at what age you will receive retirement benefits (both state and occupation benefits). If you worked for forty years and you will retire at the standard retirement age, the retirement benefits will amount $70 \%$ of your average gross income. The standard retirement age now amounts 65 years of age. One year earlier retirement means that your retirement benefits will be $7 \%$ lower for the rest of your life. One year later retirement means $7 \%$ higher retirement benefits for the rest of your life time.

We now would like to ask you questions about a fictive person.

\section{Vignette 1}

John / Lisa is not yet eligible for retirement. He / She does think about it from time to time. Given this retirement scheme John / Lisa plans to retire at 65 years of age. The most of his / her co-workers / family and friends retire at 65 years of age. When John / Lisa has turned 60, the most of his / her coworkers / family and friends retire at 66 years of age. This is a consequence of longer and healthier lives of individuals. / This is a consequence of a larger need for experienced employees by employers. / This is a consequence of financial consequences of the economic crisis. / This is a consequence of the raise in the standard retirement age in the pension scheme by one year. If John / Lisa wants to retire at the same age, he / she will receive $7 \%$ lower retirement benefits for the rest of his / her life.

What would you do in the situation of John / Lisa?

1 To retire earlier than 65 years of age

2 To retire at 65 years of age

3 To retire at 65.5 years of age

4 To retire at 66 years of age 


\section{Vignette 2}

Arnold / Marlous is not yet eligible for retirement. He / She does think about it from time to time. Given this retirement scheme Arnold / Marlous plans to retire at 65 years of age. The most of his / her co-workers / family and friends retire at 65 years of age. When Arnold / Marlous has turned 60, the most of his / her coworkers / family and friends retire at 67 years of age. This is a consequence of longer and healthier lives of individuals. / This is a consequence of a larger need for experienced employees by employers. / This is a consequence of financial consequences of the economic crisis. / This is a consequence of the raise in the standard retirement age in the pension scheme by one year. If Arnold / Marlous wants to retire at the same age, he / she will receive 7\% lower retirement benefits for the rest of his / her life.

What would you do in the situation of Arnold / Marlous?

$\begin{array}{ll}1 & \text { To retire earlier than } 65 \text { years of age } \\ 2 & \text { To retire at } 65 \text { years of age } \\ 3 & \text { To retire at } 65.5 \text { years of age } \\ 4 & \text { To retire at } 66 \text { years of age } \\ 5 & \text { To retire at } 66.5 \text { years of age } \\ 6 & \text { To retire at } 67 \text { years of age } \\ 7 & \text { To retire later than } 67 \text { years of age }\end{array}$

\section{Vignette 3}

Wim / Els is not yet eligible for retirement. He / She does think about it from time to time. Given this retirement scheme Wim / Els plans to retire at 64 years of age. The most of his / her co-workers / family and friends retire at 65 years of age. When Wim / Els has turned 60, the most of his / her coworkers / family and friends retire at 66 years of age. This is a consequence of longer and healthier lives of individuals. / This is a consequence of a larger need for experienced employees by employers. / This is a consequence of financial consequences of the economic crisis. / This is a consequence of the raise in the standard retirement age in the pension scheme by one year. If Wim / Els wants to retire at the same age, he / she will receive $7 \%$ lower retirement benefits for the rest of his / her life.

What would you do in the situation of Wim / Els?

$\begin{array}{ll}1 & \text { To retire earlier than } 64 \text { years of age } \\ 2 & \text { To retire at } 64 \text { years of age } \\ 3 & \text { To retire at } 64.5 \text { years of age } \\ 4 & \text { To retire at } 65 \text { years of age } \\ 5 & \text { To retire at } 65.5 \text { years of age } \\ 6 & \text { To retire at } 66 \text { years of age } \\ 7 & \text { To retire later than } 66 \text { years of age }\end{array}$

\section{Vignette 4}

Frans / Rachel is not yet eligible for retirement. He / She does think about it from time to time. Given this retirement scheme Frans / Rachel plans to retire at 64 years of age. The most of his / her co-workers / family and friends retire at 64 years of age. When Frans / Rachel has turned 60, the most of his / her coworkers / family and friends retire at 65 years of age. This is a consequence of longer and healthier lives of individuals. / This is a consequence of a larger need for experienced employees by employers. / This is a consequence of financial consequences of the economic crisis. / This is a consequence of the raise in the standard retirement age in the pension scheme by one year. If Frans / Rachel wants to retire at the same age, he / she will receive $7 \%$ lower retirement benefits for the rest of his / her life.

What would you do in the situation of Frans / Rachel?

1 To retire earlier than 64 years of age

2 To retire at 64 years of age

3 To retire at 64.5 years of age

4 To retire at 65 years of age

$5 \quad$ To retire at 65.5 years of age

6 To retire at 66 years of age

7 To retire later than 66 years of age 
v26

How sure are you of your answers to the previous questions?

1 Very uncertain

2

3

4

5 Very certain 


\section{Appendix C Ordered Probit Regressions}

Table C. 1 shows the ordered probit estimation for the four questions separately. The coefficients are not statistically significantly different from each other across the different vignettes. This lends support to the assumption that the coefficients of these question characteristics are the same.

Table C.1 Ordered probit estimation for the four vignettes separately.

\begin{tabular}{|c|c|c|c|c|}
\hline & Vignette 1 & Vignette 2 & Vignette 3 & Vignette 4 \\
\hline Gender vignette person ( $=1$ if female $)$ & $\begin{array}{l}-0.1072 * \\
(0.0644)\end{array}$ & $\begin{array}{l}-0.0202 \\
(0.0645)\end{array}$ & $\begin{array}{l}-0.0944 \\
(0.0630)\end{array}$ & $\begin{array}{l}-0.1043 \\
(0.0644)\end{array}$ \\
\hline $\begin{array}{l}\text { Composition social environment ( }=1 \text { if 'Friends and } \\
\text { family') }\end{array}$ & $-0.1706^{* * * *}$ & $-0.1467 * *$ & $-0.1497 * *$ & $-0.1369 * *$ \\
\hline & $(0.0644)$ & $(0.0645)$ & $(0.0630)$ & $(0.0643)$ \\
\hline More need for experienced employees & $\begin{array}{c}0.0096 \\
(0.0941)\end{array}$ & $\begin{array}{c}0.0294 \\
(0.0941)\end{array}$ & $\begin{array}{c}0.0506 \\
(0.0915)\end{array}$ & $\begin{array}{l}-0.0242 \\
(0.0933)\end{array}$ \\
\hline Financial consequences of the economic crisis & $\begin{array}{c}0.2612 * * * \\
(0.0905)\end{array}$ & $\begin{array}{c}0.3087 * * * \\
(0.0907)\end{array}$ & $\begin{array}{c}0.2745 * * * \\
(0.0883)\end{array}$ & $\begin{array}{c}0.1836 * * \\
(0.0900)\end{array}$ \\
\hline Reduction of pension rights by one year & $\begin{array}{c}0.3146 * * * \\
(0.0906)\end{array}$ & $\begin{array}{c}0.3294 * * * \\
(0.0906)\end{array}$ & $\begin{array}{c}0.2890 * * * \\
(0.0885)\end{array}$ & $\begin{array}{c}0.2972 * * * \\
(0.0904)\end{array}$ \\
\hline $\mathrm{C} 1$ & $\begin{array}{c}-1.5487 * * * \\
(0.0951)\end{array}$ & $\begin{array}{c}-1.5068 * * * \\
(0.0951)\end{array}$ & $\begin{array}{c}-1.5853 * * * \\
(0.0949)\end{array}$ & $\begin{array}{c}-1.6546^{* * * *} \\
(0.0968)\end{array}$ \\
\hline $\mathrm{C} 2$ & $\begin{array}{c}0.0459 \\
(0.0836)\end{array}$ & $\begin{array}{c}0.0525 \\
(0.0838)\end{array}$ & $\begin{array}{c}-0.3907 * * * \\
(0.0825)\end{array}$ & $\begin{array}{c}-0.3259 * * * \\
(0.0838)\end{array}$ \\
\hline $\mathrm{C} 3$ & $\begin{array}{c}0.1781 * * \\
(0.0838)\end{array}$ & $\begin{array}{c}0.1171 \\
(0.0838)\end{array}$ & $\begin{array}{c}-0.3042 * * * \\
(0.0823)\end{array}$ & $\begin{array}{c}-0.2136 * * \\
(0.0837)\end{array}$ \\
\hline $\mathrm{C} 4$ & $\begin{array}{c}1.2784 * * * \\
(0.0905)\end{array}$ & $\begin{array}{c}0.5807 * * * \\
(0.0850)\end{array}$ & $\begin{array}{c}0.5280 * * * \\
(0.0828)\end{array}$ & $\begin{array}{c}1.1884 * * * \\
(0.0887)\end{array}$ \\
\hline $\mathrm{C} 5$ & $\begin{array}{c}1.3839 * * * \\
(0.0920)\end{array}$ & $\begin{array}{c}0.6459 * * * \\
(0.0852)\end{array}$ & $\begin{array}{c}0.5878 * * * \\
(0.0830)\end{array}$ & $\begin{array}{c}1.2444 * * * \\
(0.0893)\end{array}$ \\
\hline C6 & $\begin{array}{c}2.0624 * * * \\
(0.1127)\end{array}$ & $\begin{array}{c}2.1779 * * * \\
(0.1155)\end{array}$ & $\begin{array}{c}1.7596 * * * \\
(0.0986)\end{array}$ & $\begin{array}{c}1.7718^{* * * *} \\
(0.1002)\end{array}$ \\
\hline Observations & 1113 & 1113 & 1113 & 1113 \\
\hline log likelihood & -1526 & -1591 & -1716 & -1512 \\
\hline
\end{tabular}




\section{Appendix D Threshold Estimates}

This appendix shows the estimations for the thresholds.

Table D.1 Estimation of the thresholds

\begin{tabular}{|c|c|c|c|c|c|c|}
\hline & $\tau_{i}^{1}$ & $\tau_{i}^{2}$ & $\tau_{i}^{3}$ & $\tau_{i}^{4}$ & $\tau_{i}^{5}$ & $\tau_{i}^{6}$ \\
\hline \multirow[b]{2}{*}{ female } & $-0.5865 * * *$ & $0.1884 * * *$ & 0.1253 & $0.1030 * *$ & -0.0687 & -0.0295 \\
\hline & $(0.2086)$ & $(0.0498)$ & $(0.1578)$ & $(0.0504)$ & $(0.2492)$ & $(0.0796)$ \\
\hline \multirow[b]{2}{*}{ age } & -0.0439 & $0.0389 * *$ & -0.0295 & 0.0141 & $-0.1233 * *$ & 0.0200 \\
\hline & $(0.0622)$ & $(0.0166)$ & $(0.0436)$ & $(0.0157)$ & $(0.0535)$ & $(0.0262)$ \\
\hline \multirow[b]{2}{*}{ age squared } & 0.0007 & $-0.0004 * *$ & 0.0002 & -0.0002 & $0.0011^{*}$ & -0.0002 \\
\hline & $(0.0007)$ & $(0.0002)$ & $(0.0005)$ & $(0.0002)$ & $(0.0006)$ & $(0.0003)$ \\
\hline \multirow{2}{*}{$\begin{array}{l}\text { less than } \\
1150 \text { euro }\end{array}$} & 0.6999 & -0.1295 & -0.1145 & -0.0166 & -0.1651 & -0.0121 \\
\hline & $(0.4710)$ & $(0.1101)$ & $(0.3318)$ & $(0.1171)$ & $(0.4660)$ & $(0.1937)$ \\
\hline \multirow{2}{*}{$\begin{array}{c}\text { between } 1151 \\
\text { and } 1800 \\
\text { euro }\end{array}$} & 0.3081 & $-0.2221 * * *$ & -0.1000 & $0.1996 * * *$ & $-0.7741 *$ & -0.0577 \\
\hline & $(0.2972)$ & $(0.0773)$ & $(0.2324)$ & $(0.0740)$ & $(0.4303)$ & $(0.1121)$ \\
\hline \multirow{2}{*}{$\begin{array}{l}\text { between } 1801 \\
\text { and } 2600 \\
\text { euro }\end{array}$} & $0.4284^{*}$ & -0.0921 & -0.2593 & -0.0300 & -0.4201 & 0.0186 \\
\hline & $(0.2283)$ & $(0.0577)$ & $(0.1944)$ & $(0.0588)$ & $(0.2788)$ & $(0.0957)$ \\
\hline \multirow{2}{*}{$\begin{array}{l}\text { Primary } \\
\text { school }\end{array}$} & -0.0768 & 0.1284 & $0.6951 *$ & -0.0459 & -0.2597 & 0.5849 \\
\hline & $(0.6015)$ & $(0.1543)$ & $(0.3700)$ & $(0.1431)$ & $(0.5941)$ & $(0.5437)$ \\
\hline \multirow{2}{*}{$\begin{array}{c}\text { lower } \\
\text { secondary } \\
\text { school } \\
\text { (vmbo) }\end{array}$} & $0.8809 * * *$ & $-0.1862 * * *$ & $0.4123^{*}$ & -0.0067 & 0.1906 & 0.1332 \\
\hline & $(0.2644)$ & $(0.0653)$ & $(0.2134)$ & $(0.0663)$ & $(0.3019)$ & $(0.1114)$ \\
\hline \multirow{2}{*}{$\begin{array}{c}\text { upper } \\
\text { secondary } \\
\text { school } \\
\text { (mbo+havo/v } \\
\text { wo) }\end{array}$} & 0.1543 & 0.0444 & $0.5747 * * *$ & 0.0318 & 0.1129 & 0.0709 \\
\hline & $(0.2279)$ & $(0.0561)$ & $(0.1886)$ & $(0.0559)$ & $(0.2732)$ & $(0.0891)$ \\
\hline \multirow[b]{2}{*}{ North } & $0.5166^{*}$ & -0.0809 & $0.3811^{*}$ & $-0.2001 * * *$ & 0.1997 & -0.0472 \\
\hline & $(0.2922)$ & $(0.0730)$ & $(0.2230)$ & $(0.0765)$ & $(0.3608)$ & $(0.1179)$ \\
\hline \multirow[b]{2}{*}{ East } & 0.2110 & -0.0720 & $0.4110^{* *}$ & $-0.1549 * *$ & $0.5151 *$ & -0.0932 \\
\hline & $(0.2637)$ & $(0.0653)$ & $(0.1917)$ & $(0.0622)$ & $(0.2670)$ & $(0.1005)$ \\
\hline \multirow[b]{2}{*}{ South } & 0.2132 & 0.0662 & -0.0467 & -0.0597 & 0.1367 & 0.0584 \\
\hline & $(0.2452)$ & $(0.0596)$ & $(0.2211)$ & $(0.0660)$ & $(0.3463)$ & $(0.1071)$ \\
\hline \multirow{2}{*}{$\begin{array}{c}\text { Not in a job } \\
\text { now, but } \\
\text { worked } \\
\text { before }\end{array}$} & -0.1442 & 0.0648 & 0.1514 & -0.0684 & $0.9781 * * *$ & -0.0793 \\
\hline & $(0.2755)$ & $(0.0672)$ & $(0.1956)$ & $(0.0686)$ & $(0.2716)$ & $(0.1075)$ \\
\hline \multirow[b]{2}{*}{ Rental home } & $-0.4694 *$ & 0.0267 & $-0.3604 *$ & -0.0014 & 0.4624 & -0.1676 \\
\hline & $(0.2703)$ & $(0.0640)$ & $(0.2118)$ & $(0.0621)$ & $(0.2929)$ & $(0.1073)$ \\
\hline \multirow{2}{*}{$\begin{array}{c}\text { Compound } \\
\text { interest } \\
\text { incorrect/RF/ } \\
\text { DK }\end{array}$} & 0.2653 & $-0.2093 * *$ & $0.4922 * *$ & 0.0515 & -0.1529 & -0.1212 \\
\hline & $(0.3244)$ & $(0.0921)$ & $(0.2286)$ & $(0.0888)$ & $(0.4006)$ & $(0.1484)$ \\
\hline \multirow{2}{*}{$\begin{array}{c}\text { Inflation } \\
\text { incorrect/RF/ } \\
\text { DK }\end{array}$} & $0.9140 * * *$ & $-0.1270^{*}$ & 0.0598 & $-0.1292^{*}$ & 0.2652 & -0.0908 \\
\hline & $(0.2725)$ & $(0.0743)$ & $(0.2068)$ & $(0.0785)$ & $(0.3314)$ & $(0.1460)$ \\
\hline \multirow{2}{*}{$\begin{array}{c}\text { Stock risk } \\
\text { incorrect/RF/ } \\
\text { DK } \\
\end{array}$} & 0.2308 & -0.0401 & -0.0972 & -0.0254 & -0.1130 & -0.0249 \\
\hline & $(0.2176)$ & $(0.0525)$ & $(0.1693)$ & $(0.0529)$ & $(0.2688)$ & $(0.0849)$ \\
\hline \multirow[b]{2}{*}{ Constant } & $-3.2685 * *$ & 0.5208 & -0.8062 & 0.5006 & 0.9274 & 0.4500 \\
\hline & $(1.3831)$ & $(0.3710)$ & $(0.9274)$ & $(0.3468)$ & $(1.0448)$ & $(0.5759)$ \\
\hline \multirow[t]{2}{*}{$\ln \left(\sigma_{\zeta}\right)$} & \multicolumn{6}{|c|}{$0.8536^{* * *}$} \\
\hline & \multicolumn{6}{|c|}{$(0.0296)$} \\
\hline
\end{tabular}


Standard errors in parentheses *** Statistical significance at 1\%, ** Statistical significance at 5\%, * Statistical significance at 10\%, Baseline respondent is male, completed tertiary education, has an income higher than 2601 euro, lives in the West of the Netherlands, has a job, is a homeowner and answers all three literacy questions about compound interest, inflation and stock risk correctly. 


\section{Appendix E An Unrestricted Model}

This appendix shows the estimation results of the unrestricted model in section 5.3

Table E.1 Estimation of the unrestricted model

\begin{tabular}{|c|c|c|c|c|}
\hline & Vignette 1 & Vignette 2 & Vignette 3 & Vignette 4 \\
\hline \multirow[t]{2}{*}{ Gender vignette person (=1 if female) } & -0.0140 & 0.0682 & 0.1604 & 0.1549 \\
\hline & $(0.2193)$ & $(0.2188)$ & $(0.2174)$ & $(0.2177)$ \\
\hline \multirow[t]{2}{*}{$\begin{array}{l}\text { Composition social environment (=1 if } \\
\text { 'friends and family') }\end{array}$} & $-0.5352 * *$ & -0.1261 & -0.3422 & -0.1973 \\
\hline & $(0.2155)$ & $(0.2141)$ & $(0.2133)$ & $(0.2135)$ \\
\hline \multirow[t]{2}{*}{ More need for experienced employees } & -0.3629 & -0.4925 & -0.0674 & $-0.5344 *$ \\
\hline & $(0.3146)$ & $(0.3154)$ & $(0.3120)$ & $(0.3141)$ \\
\hline \multirow[t]{2}{*}{$\begin{array}{c}\text { Financial consequences of the economic } \\
\text { crisis }\end{array}$} & -0.1836 & 0.0790 & 0.3098 & -0.2720 \\
\hline & $(0.3004)$ & $(0.2990)$ & $(0.2983)$ & $(0.2988)$ \\
\hline \multirow[t]{2}{*}{ Reduction of pension rights by one year } & 0.3347 & 0.3261 & $0.5780 *$ & 0.3179 \\
\hline & $(0.3007)$ & $(0.2995)$ & $(0.2983)$ & $(0.2980)$ \\
\hline \multirow[t]{2}{*}{ Female } & 0.0065 & 0.0660 & -0.0472 & -0.2151 \\
\hline & $(0.2341)$ & $(0.2335)$ & $(0.2320)$ & $(0.2325)$ \\
\hline \multirow[t]{2}{*}{ age } & $-0.1885^{*}$ & -0.0994 & $-0.2062 * *$ & -0.1374 \\
\hline & $(0.1006)$ & $(0.0998)$ & $(0.0998)$ & $(0.0999)$ \\
\hline \multirow[t]{2}{*}{ age squared } & $0.0020 *$ & 0.0011 & $0.0024 * *$ & 0.0016 \\
\hline & $(0.0011)$ & $(0.0011)$ & $(0.0011)$ & $(0.0011)$ \\
\hline \multirow[t]{2}{*}{ Family income less than 1150 euro } & -0.6667 & -0.6748 & 0.1419 & 0.4125 \\
\hline & $(0.8179)$ & $(0.8106)$ & $(0.8030)$ & $(0.7987)$ \\
\hline \multirow[t]{2}{*}{$\begin{array}{l}\text { Family income between } 1151 \text { and } 1800 \\
\text { euro }\end{array}$} & $0.7954 * *$ & $0.7566^{* *}$ & 0.4644 & 0.4603 \\
\hline & $(0.3464)$ & $(0.3448)$ & $(0.3436)$ & $(0.3424)$ \\
\hline \multirow[t]{2}{*}{$\begin{array}{l}\text { Family income between } 1801 \text { and } 2600 \\
\text { euro }\end{array}$} & 0.0203 & 0.2064 & 0.1351 & -0.0012 \\
\hline & $(0.2546)$ & $(0.2548)$ & $(0.2531)$ & $(0.2539)$ \\
\hline \multirow[t]{2}{*}{ Primary school } & 0.0232 & $1.9924 * *$ & 0.9568 & 0.8242 \\
\hline & $(0.9691)$ & $(0.9582)$ & $(0.9603)$ & $(0.9645)$ \\
\hline \multirow[t]{2}{*}{ lower secondary school (vmbo) } & $-0.9146 * * *$ & $-0.7010 * *$ & $-0.5395^{*}$ & $-0.6322 * *$ \\
\hline & $(0.2978)$ & $(0.2966)$ & $(0.2934)$ & $(0.2948)$ \\
\hline \multirow[t]{2}{*}{ upper secondary school (mbo+havo/vwo) } & -0.2900 & -0.1354 & -0.1329 & -0.1411 \\
\hline & $(0.2508)$ & $(0.2498)$ & $(0.2490)$ & $(0.2489)$ \\
\hline \multirow[t]{2}{*}{ Region North } & -0.3935 & -0.2459 & 0.0413 & -0.0244 \\
\hline & $(0.3340)$ & $(0.3364)$ & $(0.3333)$ & $(0.3311)$ \\
\hline \multirow[t]{2}{*}{ Region East } & -0.1243 & -0.1274 & 0.0045 & 0.0260 \\
\hline & $(0.2907)$ & $(0.2901)$ & $(0.2894)$ & $(0.2891)$ \\
\hline \multirow[t]{2}{*}{ Region South } & -0.4155 & -0.2345 & 0.3163 & 0.1250 \\
\hline & $(0.2794)$ & $(0.2770)$ & $(0.2742)$ & $(0.2765)$ \\
\hline \multirow[t]{2}{*}{ Not in a job now, but worked before } & $-0.7651 *$ & $-0.8272 *$ & $-0.9361 * *$ & -0.6451 \\
\hline & $(0.4352)$ & $(0.4386)$ & $(0.4370)$ & $(0.4336)$ \\
\hline \multirow[t]{2}{*}{ Rental home } & 0.1175 & 0.0604 & $0.5376^{*}$ & 0.4692 \\
\hline & $(0.3032)$ & $(0.3024)$ & $(0.3027)$ & $(0.3015)$ \\
\hline \multirow[t]{2}{*}{ Compound interest incorrect/RF/DK } & 0.3279 & -0.5760 & -0.2218 & -0.0940 \\
\hline & $(0.4685)$ & $(0.4685)$ & $(0.4628)$ & $(0.4622)$ \\
\hline \multirow[t]{2}{*}{ Inflation incorrect/RF/DK } & $-1.2297 * * *$ & $-1.1132 * * *$ & $-0.7179 *$ & -0.4180 \\
\hline & $(0.4199)$ & $(0.4147)$ & $(0.4116)$ & $(0.4090)$ \\
\hline Stock risk incorrect/RF/DK & -0.2155 & $-0.5051 * *$ & -0.1629 & 0.1284 \\
\hline
\end{tabular}




\begin{tabular}{|c|c|c|c|c|}
\hline & $(0.2305)$ & $(0.2297)$ & $(0.2283)$ & $(0.2288)$ \\
\hline \multirow[t]{2}{*}{ expected retirement age 64} & 0.9455 & $1.8247 * * *$ & 0.7699 & $1.0067 *$ \\
\hline & $(0.6064)$ & $(0.6084)$ & $(0.6023)$ & $(0.5989)$ \\
\hline \multirow[t]{2}{*}{ expected retirement age 65} & $1.2442 * * *$ & $1.5353 * * *$ & $1.6047 * * *$ & $1.3058 * * *$ \\
\hline & $(0.2787)$ & $(0.2790)$ & $(0.2768)$ & $(0.2760)$ \\
\hline \multirow[t]{2}{*}{ expected retirement age 66} & $0.9764 * *$ & $1.3045 * * *$ & 0.5806 & 0.5542 \\
\hline & $(0.4273)$ & $(0.4236)$ & $(0.4217)$ & $(0.4245)$ \\
\hline \multirow[t]{2}{*}{ expected retirement age 67} & $1.1133 * * *$ & $1.6333 * * *$ & $1.2119^{* * *}$ & $0.9468 * * *$ \\
\hline & $(0.3235)$ & $(0.3238)$ & $(0.3213)$ & $(0.3220)$ \\
\hline \multirow[t]{2}{*}{ expected retirement age above 67} & $2.4701 * * *$ & $3.0363 * * *$ & $2.9938 * * *$ & $2.5846 * * *$ \\
\hline & $(0.6368)$ & $(0.6334)$ & $(0.6349)$ & $(0.6331)$ \\
\hline \multirow[t]{2}{*}{ Constant } & - & -1.9863 & 0.0996 & -1.4256 \\
\hline & - & $(1.8059)$ & $(1.8117)$ & $(1.8045)$ \\
\hline \multirow[t]{2}{*}{$\tau_{i}^{1}$} & \multicolumn{4}{|c|}{$-7.2056 * * *$} \\
\hline & \multicolumn{4}{|c|}{$(2.3497)$} \\
\hline \multirow[t]{2}{*}{$\tau_{i}^{2}$} & \multicolumn{4}{|c|}{$1.1685 * * *$} \\
\hline & \multicolumn{4}{|c|}{$(0.0400)$} \\
\hline \multirow[t]{2}{*}{$\tau_{i}^{3}$} & \multicolumn{4}{|c|}{$-1.3465 * * *$} \\
\hline & \multicolumn{4}{|c|}{$(0.1142)$} \\
\hline \multirow[t]{2}{*}{$\tau_{i}^{4}$} & \multicolumn{4}{|c|}{$0.7665 * * *$} \\
\hline & \multicolumn{4}{|c|}{$(0.0402)$} \\
\hline \multirow[t]{2}{*}{$\tau_{i}^{5}$} & \multicolumn{4}{|c|}{$-2.0024 * * *$} \\
\hline & \multicolumn{4}{|c|}{$(0.1795)$} \\
\hline \multirow[t]{2}{*}{$\tau_{i}^{6}$} & \multicolumn{4}{|c|}{$0.9218 * * *$} \\
\hline & \multicolumn{4}{|c|}{$(0.0604)$} \\
\hline \multirow[t]{2}{*}{$\ln \left(\sigma_{\zeta}\right)$} & \multicolumn{4}{|c|}{$0.6567 * * *$} \\
\hline & \multicolumn{4}{|c|}{$(0.0455)$} \\
\hline Log likelihood & \multicolumn{4}{|c|}{-1978} \\
\hline Number of observations & \multicolumn{4}{|c|}{465} \\
\hline
\end{tabular}

Standard errors in parentheses *** Statistical significance at 1\%, ** Statistical significance at 5\%, ${ }^{*}$ Statistical significance at $10 \%$, Baseline respondent is male, completed tertiary education, has an income higher than 2601 euro, lives in the West of the Netherlands, has a job, is a homeowner and answers all three literacy questions about compound interest, inflation and stock risk correctly and expects to retire before 64 years of age. 
Publisher:

CPB Netherlands Bureau for Economic Policy Analysis

P.O. Box $80510 \mid 2508$ GM The Hague

$\mathrm{T}(070) 3383380$

June 2014 | ISBN 978-90-5833-644-8 